University of Tennessee Health Science Center

UTHSC Digital Commons

\title{
D2R Dopamine Receptor Mediates Changes in Dual Specificity Phosphatase Expression in a Small Cell Lung Cancer Cell Line
}

\author{
Scott Lemar Lattimer \\ University of Tennessee Health Science Center
}

Follow this and additional works at: https://dc.uthsc.edu/dissertations

Part of the Medical Cell Biology Commons

\section{Recommended Citation}

Lattimer, Scott Lemar , "D2R Dopamine Receptor Mediates Changes in Dual Specificity Phosphatase Expression in a Small Cell Lung Cancer Cell Line" (2010). Theses and Dissertations (ETD). Paper 149. http://dx.doi.org/10.21007/etd.cghs.2010.0173.

This Thesis is brought to you for free and open access by the College of Graduate Health Sciences at UTHSC Digital Commons. It has been accepted for inclusion in Theses and Dissertations (ETD) by an authorized administrator of UTHSC Digital Commons. For more information, please contact jwelch30@uthsc.edu. 


\title{
D2R Dopamine Receptor Mediates Changes in Dual Specificity Phosphatase Expression in a Small Cell Lung Cancer Cell Line
}

\author{
Abstract \\ (PA) produced from Phospholipase $D$ (PLD) is involved in this induction.

\section{Document Type} \\ Thesis

\section{Degree Name} \\ Master of Science (MS)

\section{Program} \\ Biomedical Sciences \\ Research Advisor \\ Susan E. Senogles, Ph.D. \\ Keywords \\ Arachidonic Acid, Dopamine, Dusp, ERK, MKP, Proliferation \\ Subject Categories \\ Medical Cell Biology | Medical Sciences | Medicine and Health Sciences
}

Bromocriptine, a D2 dopamine receptor (D2R) agonist, is used clinically as a treatment for pituitary tumors of a lactotroph origin. Many questions remain unanswered about the mechanism of this effect. The antiproliferative effect has not been demonstrated in DMS 53 cell line, a Small Cell Lung Cancer (SCLC). In this thesis, we have shown that treatment with NPA (N-propylnorapomorphine), a dopamine receptor agonist inhibits ERK phosphorylation and proliferation in DMS 53 cells. NPA treatment causes significant increases in DUSP-1 (MKP-1), DUSP-4 (MKP-2) and DUSP5 mRNA. NPA treatment also correlates with increases in DUSP5 (hVHR3) protein visualized using Western Blot. These three genes were also induced by treatment with exogenous arachidonic acid (AA). In addition, the NPA mediated increases in these genes was inhibited by 5,8,11,14-eicosatetraynoic acid (ETYA) an AA analog and inhibitor of downstream activity, suggesting NPA induction of these three genes is AA dependent. Ethanol treatment leads to inhibition of the NPA induction of DUSP4 and DUSP5, suggesting phosphatidic acid 


\title{
D2R Dopamine Receptor Mediates Changes in Dual Specificity Phosphatase Expression in a Small Cell Lung Cancer Cell Line
}

\author{
A Thesis \\ Presented for \\ The Graduate Studies Council \\ The University of Tennessee \\ Health Science Center
}

\author{
In Partial Fulfillment \\ Of the Requirements for the Degree \\ Master of Science \\ From The University of Tennessee
}

By

Scott Lemar Lattimer

December 2010 
Portions of Chapter 1 Copyright (C) 1998 by The American Physiological Society. Portions of Chapter 1 Copyright (C) 2007 Nature Publishing Group. All other material Copyright $\mathbb{C} 2010$ by Scott Lattimer. All rights reserved. 


\section{ACKNOWLEDGEMENTS}

I would like to express my gratitude to those who have aided in my completion of the Master of Science degree. First, I would like to thank my mentor, Dr. Susan Senogles for providing me with her knowledge, willingness to listen and most of all patience. I would also like to thank my committee members Dr. Rennolds Ostrom, Dr. Satoru (Ken) Nishimoto, Dr. K.U. Malik and Dr. Lawrence Pfeffer for their advice along the way. I would also like to acknowledge Dr. William Taylor who offered his assistance and knowledge in developing primers and carrying out real time PCR. Finally, I would like to thank my wife, Nansi, and my children, Shanae and Ami, for without their selflessness and patience, this thesis would never have been completed. 


\begin{abstract}
Bromocriptine, a D2 dopamine receptor (D2R) agonist, is used clinically as a treatment for pituitary tumors of a lactotroph origin. Many questions remain unanswered about the mechanism of this effect. The antiproliferative effect has not been demonstrated in DMS 53 cell line, a Small Cell Lung Cancer (SCLC). In this thesis, we have shown that treatment with NPA (N-propylnorapomorphine), a dopamine receptor agonist inhibits ERK phosphorylation and proliferation in DMS 53 cells. NPA treatment causes significant increases in DUSP-1 (MKP-1), DUSP-4 (MKP-2) and DUSP5 mRNA. NPA treatment also correlates with increases in DUSP5 (hVHR3) protein visualized using Western Blot. These three genes were also induced by treatment with exogenous arachidonic acid (AA). In addition, the NPA mediated increases in these genes was inhibited by 5,8,11,14-eicosatetraynoic acid (ETYA) an AA analog and inhibitor of downstream activity, suggesting NPA induction of these three genes is AA dependent. Ethanol treatment leads to inhibition of the NPA induction of DUSP4 and DUSP5, suggesting phosphatidic acid (PA) produced from Phospholipase D (PLD) is involved in this induction.
\end{abstract}




\section{TABLE OF CONTENTS}

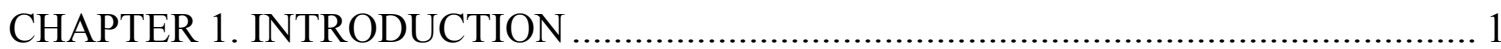

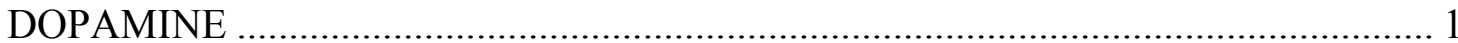

Distribution of Dopamine Signaling .................................................................. 1

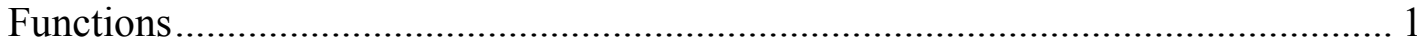

Epidemiology/Involvement in Diseases ............................................................ 1

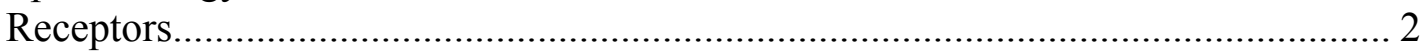

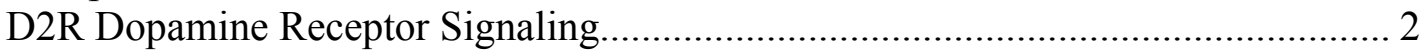

D2R DOPAMINE RECEPTOR MEDIATED CHANGES IN

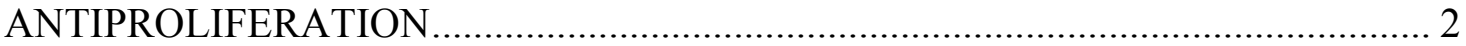

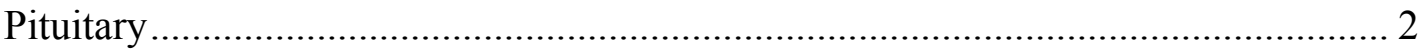

Small Cell Lung Cancer (SCLC) .......................................................................... 4

POTENTIAL PATHWAYS FOR SIGNALING IN ANTIPROLIFERATION............. 5

Lipid Metabolism..................................................................................... 5

Inhibition of Downstream Signaling from PLD by the Addition of Primary

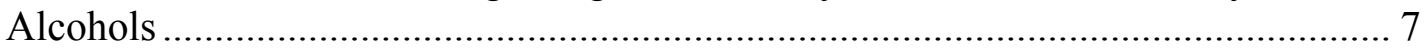

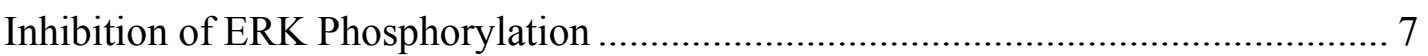

Dual Specificity Phosphatases (DUSPs)............................................................. 8

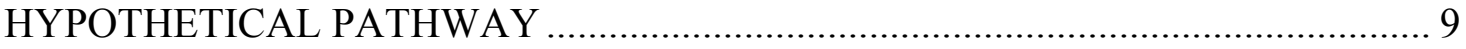

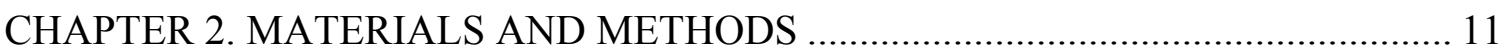

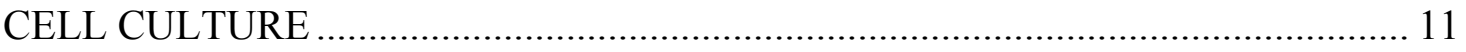

NPA TREATMENT AND CYQUANT NF CELLULAR PROLIFERATION

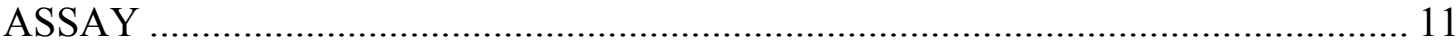

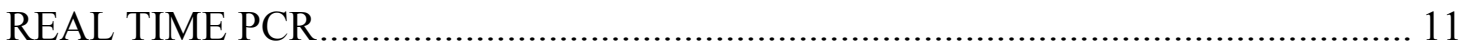

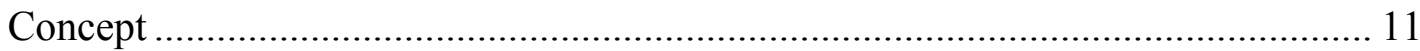

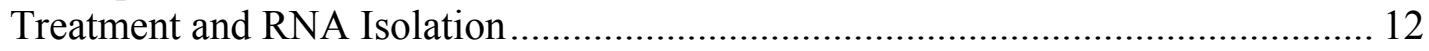

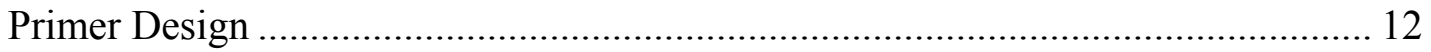

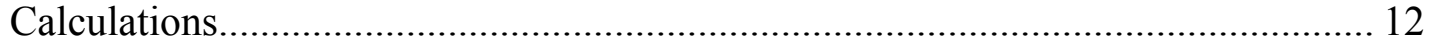

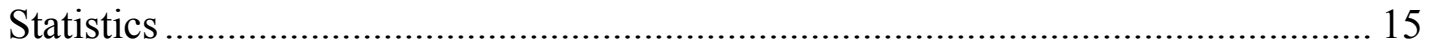

Selection of Cyclophilin D as a Reference Gene................................................ 17

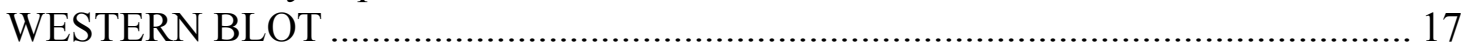

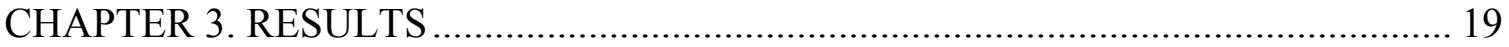

D2R DOPAMINE RECEPTOR MEDIATED ANTIPROLIFERATION IN DMS 53

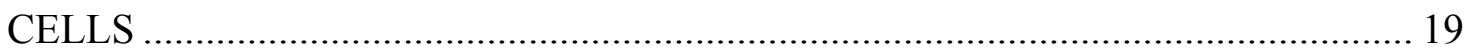

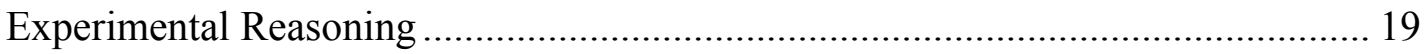

Results of D2R Mediated Antiproliferation........................................................ 19

Discussion of D2R Mediated Antiproliferation...................................................... 20

D2R RECEPTOR STIMULATED REDUCTION OF pERK IMMUNOREACTIVITY

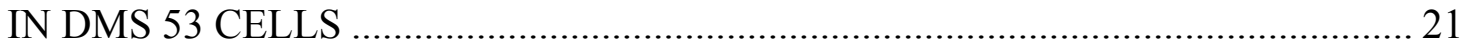

Experimental Reasoning .............................................................................. 21

Results of pERK Western Blot Analysis ............................................................ 21

Discussion of pERK Western Blot Analysis .......................................................... 21 


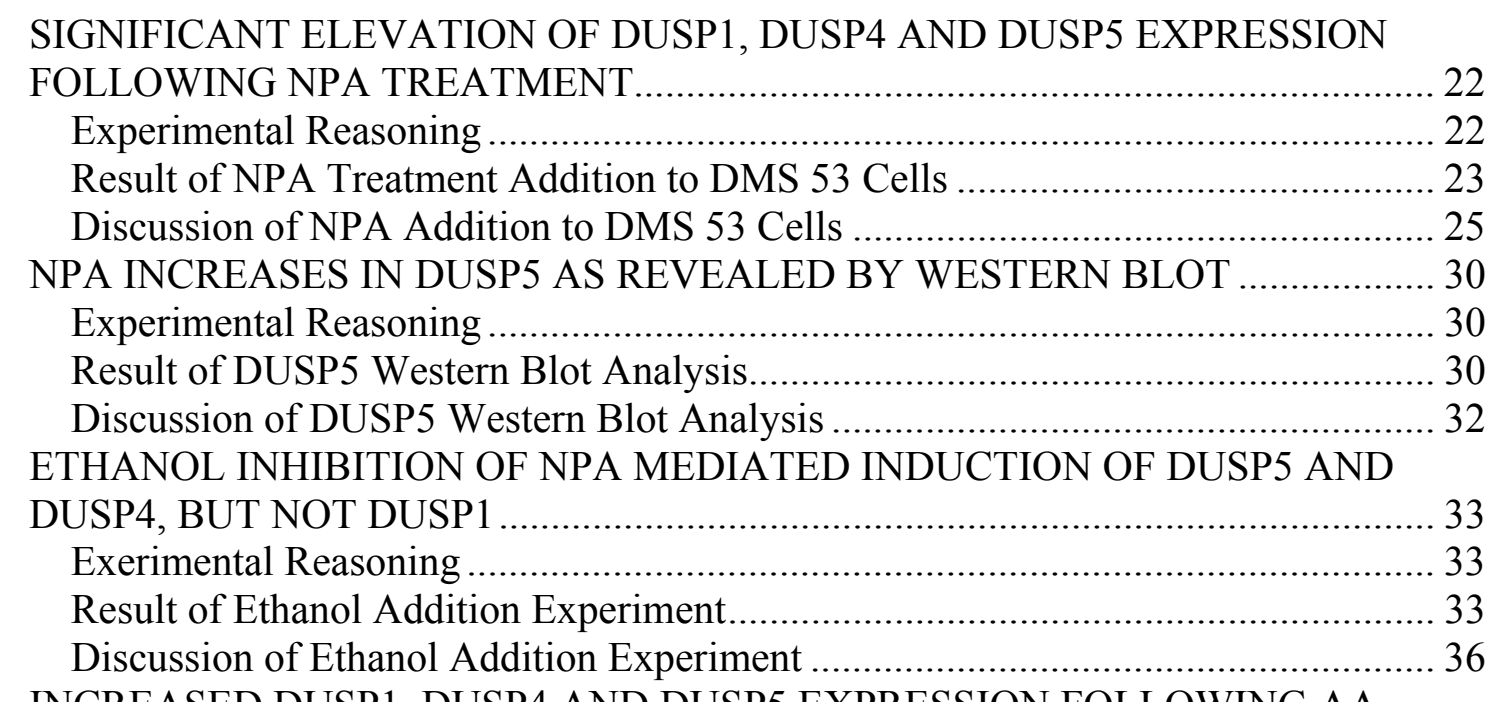

INCREASED DUSP1, DUSP4 AND DUSP5 EXPRESSION FOLLOWING AA

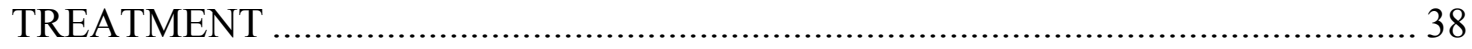

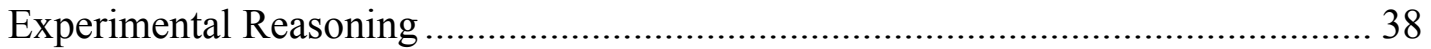

Result of AA Treatment of DMS 53 Cells............................................................ 38

Discussion of AA Treatment of DMS 53 Cells ....................................................... 41

REDUCTION OF DUSP1, DUSP4 AND DUSP5 INDUCTION BY NPA

FOLLOWING ADDITION OF AA INHIBITORS................................................. 41

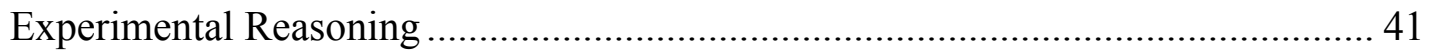

Result of ETYA Addition to DMS 53 Cells ........................................................... 44

Discussion of ETYA Addition to DMS 53 Cells..................................................... 46

CHAPTER 4. SUMMARY/CONCLUSION ................................................................. 48

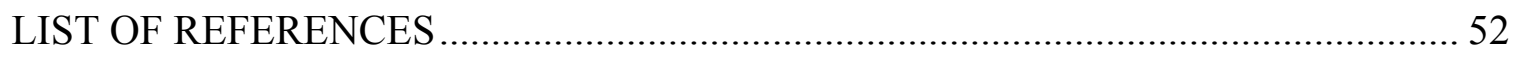

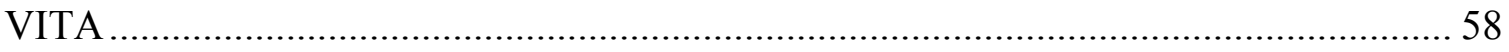




\section{LIST OF FIGURES}

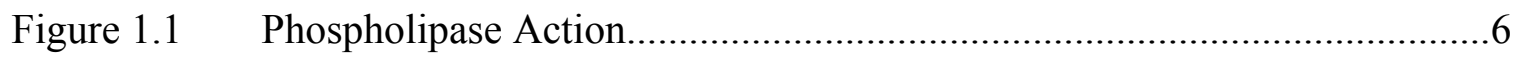

Figure 1.2 Hypothetical Pathway ………………................................................10

Figure 2.1 Real Time PCR Amplification Curves ……………………………....16

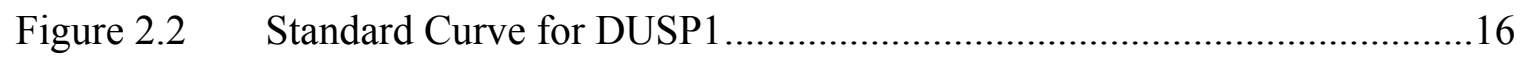

Figure 3.1 NPA Inhibition of Proliferation in DMS 53 Cells ..................................20

Figure 3.2 pERK Immunoreactivity following NPA Treatment .................................22

Figure 3.3 Real Time PCR Analysis of DUSP1 Expression in DMS 53 Cells

following Addition of NPA, a D2R Agonist ............................................24

Figure 3.4 Real Time PCR Analysis of DUSP4 in DMS 53 Cells following

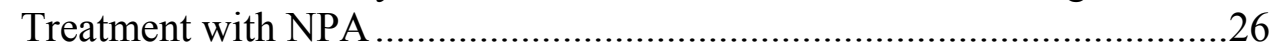

Figure 3.5 Real Time PCR Analysis of DUSP5 in DMS 53 Cells following

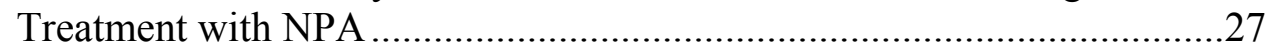

Figure 3.6 Real Time PCR Analysis of DUSP2 in DMS 53 Cells following

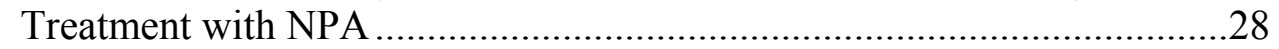

Figure 3.7 Real Time PCR Analysis of DUSP Family Members in DMS 53 Cells

following NPA Treatment........................................................................29

Figure 3.8 Western Blot of DUSP 5 Protein Expression Time Course after

Treatment with NPA

Figure 3.9 Western Blotting of NPA Induction of DUSP5 Using NCI-1876 Cells as a Negative Control.

Figure 3.10 Effect of Ethanol on DUSP5 Expression as Revealed by Real Time

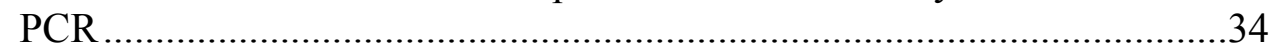

Figure 3.11 Effect of Ethanol on DUSP4 Expression as Revealed by Real Time

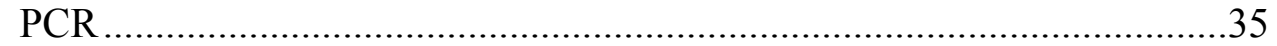

Figure 3.12 Effect of Ethanol on DUSP1 Expression as Revealed by Real Time PCR 
Figure 3.13 Effect of AA on DUSP1 Expression as Revealed by Real Time PCR Analysis

Figure 3.14 Effect of AA on DUSP4 Expression as Revealed by Real Time PCR

Analysis

Figure 3.15 Effect of AA on DUSP5 Expression as Revealed by Real Time PCR

Analysis

Figure 3.16 Effect of AA on DUSP Expression as Revealed by Real Time PCR

Analysis

Figure 3.17 Effect of $10 \mu \mathrm{M}$ ETYA Added to $1 \mu \mathrm{M}$ NPA Treatment on DUSP1 as Revealed by Real Time PCR .................................................................4

Figure 3.18 Effect of $10 \mu \mathrm{M}$ ETYA Added to $1 \mu \mathrm{M}$ NPA Treatment on DUSP5 as Revealed by Real Time PCR .45

Figure 3.19 Effect of $10 \mu \mathrm{M}$ ETYA Added to $1 \mu \mathrm{M}$ NPA Treatment on DUSP4 Expression as Revealed by Real Time PCR

Figure 4.1 Proposed Mechanism for D2R Mediated Antiproliferation. .50 


\section{LIST OF ABBREVIATIONS}

$\begin{array}{ll}\text { AA } & \text { 5,8,11,14-eicosatetraenoic acid, arachidonic acid } \\ \text { CHO cells } & \text { Chinese hamster ovary cells } \\ \text { COX } & \text { cycloxygenase } \\ \text { CP } & \text { crossing point } \\ \text { cPLA2 } & \text { cytosolic phospholipase A2 } \\ \text { D2R } & \text { D2 dopamine receptor } \\ \text { D2R1 } & \text { D2 dopamine receptor long } \\ \text { D2Rs } & \text { D2 dopamine receptor short } \\ \text { DA } & \text { dopamine } \\ \text { DMSO } & \text { dimethyl sulfoxide } \\ \text { DUSPs } & \text { dual specificity phosphatases } \\ \text { ERK } & \text { extracellular signal related kinase } \\ \text { ETYA } & \text { 5,8,11,14-eicosatetraynoic acid } \\ \text { HEK cells } & \text { human embryonic kidney cells } \\ \text { HRP } & \text { horseradish peroxidase } \\ \text { JNK } & \text { c-jun N-terminal kinase } \\ \text { LOX } & \text { lipoxygenase } \\ \text { MAPK } & \text { mitogen activated protein kinase } \\ \text { MEK } & \text { mitogen activated ERK specific kinase } \\ \text { MKP } & \text { MAP kinase phosphatase } \\ \text { NGF } & \text { nerve growth factor } \\ \text { NPA } & \text { N-propylnorapomorphine (D2R agonist) } \\ \text { PA } & \text { phosphatidic acid } \\ \text { PAP } & \text { phosphatidic phosphohydrolase } \\ \text { PC } & \text { phosphatidylcholine } \\ \text { pERK } & \text { phosphorylated ERK } \\ \text { PIP2 } & \text { phosphatidylinositol-4,5 bisphosphate } \\ \text { PLA2 } & \text { Phospholipase A2 } \\ \text { PLC } & \text { Phospholipase C } \\ \text { PLD } & \text { Phospholipase D } \\ \text { R.I.N. } & \text { RNA integrity number } \\ \text { SAPK } & \text { stress activated protein kinase } \\ \text { SCLC } & \text { Small Cell Lung Cancer } \\ & \end{array}$




\section{CHAPTER 1. INTRODUCTION}

\section{DOPAMINE}

\section{Distribution of Dopamine Signaling}

Dopamine (DA) is a catecholamine derived from Tyrosine in a two step enzymatic process. The limiting step in this process, catalyzed by L-Dopa Decarboxylase removes the carboxyl group from L-Dopa (Nolte 2002). DA neurons are found in the olfactory bulb, the hypothalamus and the in the ventral midbrain. Substantia nigra pars compacta neurons project through the nigrostriatal pathway to the striatum (London 2002), while Ventral Tegmental Area neurons project to a variety of locations throughout the central nervous system (Prakash 2006; Sillitoe 2008). Neurons in the Ventral Tegmental area project through the mesocortical and mesolimbic pathways to regulate a multitude of behavioral functions (Sillitoe 2008). DA neurons in the olfactory bulb are involved in processing sensory information from olfactory receptor neurons (Cave 2009). Hypothalamic Neurons project to cells through the tuberoinfundibular pathway to the pituitary (Prakash 2006; Wojcikowski 2009).

\section{Functions}

CNS DA signaling regulates mood, cognition, attention, reward, reinforcement of addiction, and stress, motor control and neuroendocrine control (Bjorklund 2007; Missale et al 1998; Schulz 2007; Sillitoe 2008; Smidt 2003; Wise 2004). In the periphery, DA regulates vascular tone, catecholamine release, hormone secretion, renal action and gastrointestinal motility (Missale 1998). DA indirectly influences changes in the periphery, by regulating circulating growth hormone and triiodothyronine levels (Wojcikowski 2009).

\section{Epidemiology/Involvement in Diseases}

A number of drugs interact with the DA receptor family, including the antipsychotics and tricyclic antidepressants. For example, DA antagonists such as Haloperidol are used as antipsychotic drugs in the treatment of schizophrenia (Kuroki 2008). DA is implicated in a multitude of other diseases such, ADHD (Kieling 2010), Parkinson's disease (Hornykiewicz 2008; Prakash 2006), in addition to reinforcement of addictions to drugs and alcohol (Ross and Peselow 2009; Sillitoe 2008). 


\section{Receptors}

DA receptors are classic G-Protein coupled receptors with seven transmembrane domains. Five DA receptors exist, which are encoded by distinct genes, $\mathrm{D}_{1}-\mathrm{D}_{5}$. DA receptors signal to a variety of cellular signaling functions, including activation or inhibition of adenylyl cyclase (Stoof and Kebabian 1984), activation of potassium conductance (Sasaki and Sato 1987), the inhibition of votage-gated calcium currents (Lledo 1992), inositol phosphate production (Mahan 1990), AA metabolism (Kanterman 1991; Piomelli 1991) and stimulation of PLD (Senogles 2000). DA receptors are grouped into two classes based on the ability to activate (D1R-like) or inhibit (D2R-like) adenylyl cyclase (Stoof and Kebabian 1984). The various DA receptors also differ in binding affinities for agonists and antagonists (Table 1.1) (Missale 1998).

\section{D2R Dopamine Receptor Signaling}

Activation of D2R DA receptors inhibits adenylyl cyclase (De Camilli 1979; McDonald 1984), voltage gated calcium currents (Lledo 1992) and activates potassium conductance (Einhorn 1991) and stimulates PLD (Senogles 2000). D2R DA receptors (D2R) exist in two different isoforms, D2R Long (D2R1) and D2R short (D2Rs) a result of alternative mRNA splicing (Dal Toso 1989). To date, all tissues which express D2R DA receptors express both isoforms, but at different ratios (Mansour 1989; Watson 1990).

\section{D2R DOPAMINE RECEPTOR MEDIATED CHANGES IN ANTIPROLIFERATION}

\section{Pituitary}

Prolactin secreting pituitary adenomas have been treated clinically using Bromocriptine, a D2R agonist for many years (Colao 2002; Melmed 1998; Wass 1979). DA agonists have also been shown to reduce tumor mass of pituitary adenomas in patients (McGregor 1979). Addition of DA agonists has been shown to inhibit proliferation in anterior pituitary cells (Pawlikowski 1978) and primary lactotroph cultures (Stepien 1978). The antiproliferative effects of DA happen in the presence or absence of serum in the culture medium (Florio 1992; Senogles 1994). In contrast, stimulation of proliferation has been reported in D2R transfected Chinese hamster ovary (CHO) cells and C6 Glioma cell lines. In these cases, the proliferative effect was inhibited with pertussis toxin, indicating the involvement of Gi/o family of G-proteins and is most likely mediated by cAMP. However, the antiproliferative effect is pertussis toxin insensitive, suggesting another signaling pathway is involved (Senogles 2000).

The GH4C1 cell line has been widely used to study the antiproliferative effects of DA. This cell line was cloned from a rat pituitary tumor and secretes prolactin and growth hormone, mimicking isolated primary lactotrophs in culture (Tashjian 1968). However, 
Table 1.1. Inhibition Constants for Dopamine Receptor Antagonists and Agonists.

\begin{tabular}{|c|c|c|c|c|c|}
\hline \multirow{2}{*}{ Receptor } & \multicolumn{2}{|c|}{ D1 like } & \multicolumn{3}{|c|}{ D2R like } \\
\hline & D1R & D5R & $\mathrm{D} 2 \mathrm{R}$ & D3R & D4R \\
\hline \multicolumn{6}{|l|}{ Antagonists } \\
\hline$(+)$-Butaclamol & ++++ & +++ & ++++ & ND & +++ \\
\hline Chlorpromazine & ++ & ++ & ++++ & +++ & +++ \\
\hline Clozapine & ++ & ++ & ++ & ++ & +++ \\
\hline Eticlopride & - & - & +++++ & ND & ++++ \\
\hline Haloperidol & ++ & ++ & +++++ & +++ & ++++ \\
\hline Nemonapride & ND & ND & +++++ & +++++ & +++++ \\
\hline Spiperone & ++ & + & +++++ & ++++ & +++++ \\
\hline \multicolumn{6}{|l|}{ Agonists } \\
\hline Apomorphine & + & ++ & ++++ & +++ & ++++ \\
\hline Bromocriptine & ++ & ++ & ++++ & ++++ & ++ \\
\hline Dopamine & + & ++ & ++ & +++ & +++ \\
\hline 7-OH-DOPAT & + & ND & +++ & ++++ & + \\
\hline Quinpirole & - & ND & + & +++ & +++ \\
\hline
\end{tabular}

Note: +++++ , Inhibition constant $(\mathrm{K})<0.5 \mathrm{nM} ;++++, 0.5 \mathrm{nM}<\mathrm{K}<5 \mathrm{nM}$;

,$+++ 5 \mathrm{nM}<\mathrm{K}<50 \mathrm{nM} ;++, 50 \mathrm{nM}, \mathrm{K}<500 \mathrm{nM} ;+, 500 \mathrm{nM}<\mathrm{K}<5 \mu \mathrm{M}-, \mathrm{K}>5 \mu \mathrm{M} ; \mathrm{ND}$, not determined; 7-OH-DPAT, 7-hydroxy-dipropylaminoetetralin. Modified with permission. Missale C, Russle N, Robinson S, Jaber M, Caron M. (1998). Dopamine receptors: from structure to function. Physiological Reviews. 78(1):189-220. 
GH4C1 cells do not endogenously express D2R (Cronin 1980) and thus are unresponsive to DA (Malarkey 1977). GH4ZR7 cells (Albert 1990) and GH4-121 cell lines (Senogles 1994) were created by stably transfecting GH4 C1 cells with the cDNA coding for the D2Rs DA receptor.

Bromocriptine (Florio 1992), DA and NPA (Senogles 1994) treatment of the GH4ZR7 cell line inhibits proliferation, as demonstrated by reduced $\left[{ }^{3} \mathrm{H}\right]$ thymidine incorporation and a reduction in cell number.

One group reported that the reduction in growth correlated with an increase in protein tyrosine phosphatase activity and that the reduction of proliferation was inhibited by pertussis toxin at concentrations of $180 \mathrm{ng} / \mathrm{ml}$ (Florio 1992). Senogles (1994) reported that at concentrations of $20 \mathrm{ng} / \mathrm{ml}$ pertussis toxin had no effect on the D2R mediated antiproliferation. This author also demonstrated complete ADP-ribosylation of Gi/Go by this concentration of pertussis toxin. Pertussis toxin insensitivity indicates the antiproliferative effect does not require the heterotrimeric $G_{i} / G_{0}$ family of $G$ Proteins (Fields and Casey 1997). Since the D2R mediated signaling effects on inhibition of adenylyl cyclase, inhibition of voltage gated calcium channels and activation of voltage gated calcium channels are in fact inhibited by pertussis toxin this suggests the existence of other D2R mediated pathways.

Phorbol Ester downregulation of Protein Kinase C (PKC) blocked DA inhibition of prolactin release in primary lactotrophs (Summers 1985). Thus, PKC was investigated as a signaling intermediate in the antiproliferation signaling pathway. In GH4ZR7 cells, down-regulation of PKC by phorbol esters and selective downregulation of PKC epsilon by Thyrotropin Releasing Hormone abolished D2R inhibition of $\left[{ }^{3} \mathrm{H}\right]$ thymidine incorporation (Senogles 1994) and suggested a PKC intermediate.

Typical isoforms of PKC are activated by DAG. Activation of Phospholipase C, (PLC) which generates DAG and inositol phosphate (IP3) by the hydrolysis of (PIP2), was a potential source of DAG. However, D2Rs signaling did not stimulate increased inositol phosphate metabolism in lactotrophs (Vallar 1990) or GH4C1 cells (Senogles 1994).

Another cellular source of DAG is from PA by the action of PLD. PLD activity was stimulated by D2Rs in GH4-121 cells (Senogles 2000). The activation of PLD was reported to be dependent on RhoA (Senogles 2003), but independent of PLC activation (Senogles 2000). Treatment of cells with $0.5 \%$ Ethanol resulted in inhibition of D2Rs mediated antiproliferation in these cells (Senogles 2003), which further implicated the role of PLD.

\section{Small Cell Lung Cancer (SCLC)}

The antiproliferative effect of DA agonists has also been in seen in SCLC, when D2R agonists inhibited growth of tumor xenografts of SCLC cell lines NCI-H69 and COR L103 in athymic nude mice (Ishibashi 1994). The antiproliferative effect, in response to a 
DA agonist, was in fact demonstrated through a reduction of $\left[{ }^{3} \mathrm{H}\right]$ thymidine incorporation as well as reduced cell number in NCI-H69 cells, a clonal SCLC cell line (Senogles 2007).

Pituitary cells required transfection of the cDNA encoding the D2R in order to study the antiproliferative pathway. Questions arise about artifacts existing resulting from D2R transfection. SCLC cells provide a possible model to study antiproliferation without transfection. A SCLC cell line NCI-H69 expresses both the D2Rs and D2R1 isoforms as shown by PCR and real time PCR (Cooper and Sprio 2006; Senogles 2007).

Approximately $20-25 \%$ of lung cancers were of the small cell variety in 1994 (Chia 1994). That number has decreased in the past 30 years (Field and Duffy 2008) and now represents about 13\% of newly diagnosed lung cancer cases (Puglisi 2010). Small Cell Lung Cancer (SCLC) is an aggressive form of cancer with early local and distant metastases (Puglisi 2010). The prognosis of SCLC cases is poor even with early diagnosis. SCLC responds initially to chemotherapy and radiation, but becomes resistant. Due to a high reoccurrence rate and development of drug resistance (ZangemeisterWittke and Stahel 1999), only $20-40 \%$ of limited diagnoses and 5\% of extensive diagnoses patients survive greater than two years (Lally 2007; Puglisi 2010). More than $90 \%$ of cases involved patients with a history of smoking (Brownson 1992).

\section{POTENTIAL PATHWAYS FOR SIGNALING IN ANTIPROLIFERATION}

\section{Lipid Metabolism}

Activation of the D2Rs stimulates PLD in stably transfected D2Rs transfected GH4C1 cells, HEK 293 cells (Senogles 2000) and in native NCI-H69 cells (Senogles 2007). PLD enzymes respond to many different stimuli including cytokines, growth factors neurotransmitters resulting in abundant amount of cellular processes to include mitogenesis, oncogenesis and metabolic regulation (Exton 2002). Phospholipase enzymes catalyze the hydrolysis of ester or phosphodiester linkages of phospholipids (Morris 1997). PLD (Figure 1.1) catalyzes the hydrolysis of Phophatidylcholine (PC) resulting in the formation of phosphatidic acid (PA) and choline (Exton 2002).

Two form of PLD exist, namely PLD1 and PLD2 (Hammond 1995). PLD1 has a low basal activity and is regulated by a number of different factors such as many cytokines, hormones, neurotransmitters (Exton 2002). Protein Kinase $\mathrm{C}$ along with members of the Ras superfamily of low molecular weight GTP binding proteins, particularly ADP

Ribosylation factor (ARF) and RhoA (Hammond 1995; 1997; Kanaho 1996) activatate PLD1. PLD2 exhibits a high basal activity (Exton 2002), however is regulated by PKC and ARF (Weernink 2007).

PA signaling is responsible for many of the cellular actions resulting from PLD 


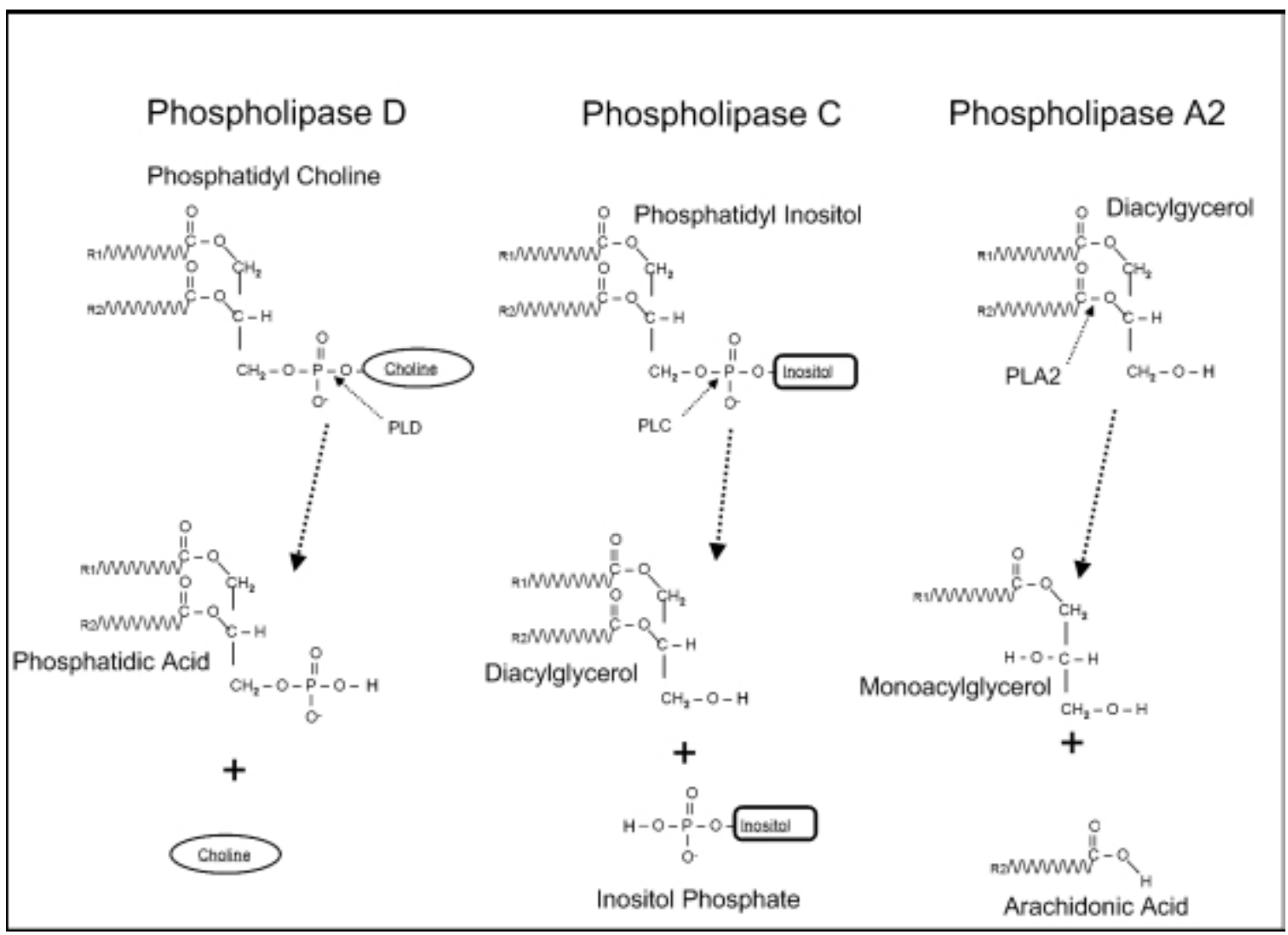

Figure 1.1. Phospholipase Action. Phospholipase D catalyzes the hydrolysis of phosphatidyl choline to phosphatidic acid and choline. Phospholipase $\mathrm{C}$ catalyzes the hydrolysis of phosphatidyl inositol species to diacylglycerol and inositol phosphate. PLA2 catalyzes the cleavage of diacylglycerol to monoacylglycerol and AA.

activation. PA can be further metabolized to DAG through phosphatidic phosphohydrolase (PAP) or to lysophosphatidic acid as catalyzed by phospholipase $\mathrm{A}_{2}$ (PLA2) (Exton 2002). In these cells, PA is involved in many processes to include membrane trafficking, actin cytoskeleton remodeling, cell proliferation and cell survival (Weernink 2007). AA $(5,8,11,14$-eicosatetraenoic acid), a 20 carbon fatty acid is metabolized through several pathways, including the cycloxygenase (COX) pathway, lipoxygenase (LOX) pathway and epoxygenase pathway (Irvine 1982; Sigal 1991). Experimental evidence supports the role of AA in a pathway not associated with classical Gi/Go stimulated adenylyl cyclase. D2R have been known to generate AA independent of adenylyl cyclase in anterior pituitary cells (Canonico 1989) and in Chinese hamster ovary cells (Kanterman 1991; Piomelli 1991). In transfected CHO cells, AA release was dependent on PKC, calcium (Piomelli 1991) and cytosolic PLA2 (Piomelli and Vial 1995). 


\section{Inhibition of Downstream Signaling from PLD by the Addition of Primary Alcohols}

PLD activity is measured by a transphosphatidylation reaction where, in the presence of primary alcohols, the alcohols substitute for water in the hydrolysis reaction, forming phosphatidyl alcohol product (Morris 1997). Thus, when ethanol is added to cultured cells, PLD will form the product, phosphatidylethanol which can be distinguished from PA on the basis of its migration on a thin layer chromatography plate. The phosphatidyl alcohol is generated instead of the naturally occurring PA and as a result, addition of ethanol to cells in culture inhibits downstream PA signaling due to the production of phosphatidyl ethanol.

\section{Inhibition of ERK Phosphorylation}

Unpublished results from our laboratory suggest that agonist-stimulation of D2R stimulation in in NCI H69 cells, a SCLC cell line, led to a reduction in phosphorylated ERK (pERK) levels. It was determined by Western blotting with a pERK specific antibody, that NPA treatment of cells would result in a reduced immunoreactivity. In addition, lysates from these cells were used in an in vitro kinase reaction and showed that the ERK kinase activity was also reduced. This data suggests that either the upstream kinase, MEK was inhibited or that a phosphatase was activated. Our laboratory has previously demonstrated that MEK activity was not changed by addition of NPA, so we focused our attention on the possibility of involvement of ERK specific phosphatases.

ERK $1 / 2$ are members of the MAP kinase family. Mitogen-activated protein kinases (MAPKs) constitute a family of proteins central to many cellular functions, including proliferation, differentiation, cytoskeletal rearrangement, immune function, stress responses and apoptosis. The extracellular signal-related kinases (ERKs) were the first MAPKs elucidated and are comprised of p42 and p44 (ERK 1/2) and ERK 5. The stress activated protein kinases (SAPKs) are further broken down into the c-Jun N-terminal kinases (JNKs), consisting of (JNK 1, JNK 2 and JNK 3) and the p38 MAPKs (alpha, beta, gamma, delta) (Zhou 2004). MAPKs are activated by dual phosphorylation of a T$\mathrm{X}-\mathrm{Y}$ motif, whereby both phosphorylation events are required to activate kinase activity. Classic signaling of MAPKs involves a three level cascade where each kinase in the cascade is activated through phosphorylation by an upstream kinase (Zhou 2004). Signaling occurs through a variety of receptors such as seven transmembrane receptors (Caunt 2006) or receptor tyrosine kinases (McCay 2007).

Many questions about the mechanism in which ERKs participate in response to multiple stimuli remain unanswered. While ERK phosphorylation was originally believed to be the only determinant required for ERK activation, evidence has shown other factors are required (Caunt 2006). The strength, duration of the signal, as well as localization, play significant roles in the differential responses to agonists. Epidermal growth factor (EGF)induced proliferation depends on transient activation of ERK1/2 in the cytosol, whereas nerve growth factor (NGF)-induced differentiation requires a sustained activation and translocation to the nucleus (Keyse 2006). 
Varied cellular responses to different stimuli are due to the number of factors which interact with ERK. A large number of ERK substrates exist, including other kinases, phosphatases and transcription factors. Some of these factors regulate transcription of immediate early genes, resulting in quick and dramatic changes in gene expression (Caunt 2006).

In addition to many different substrates, a wide variety of upstream activators exist. This effect is compounded as a large number of isoforms exist at all three tiers of the MAPK cascade. The ability to interact with both upstream regulators and downstream targets is critical in determining the outcome of MAPK signaling. These interactions depend on localization, compartmentalization and scaffolding molecules (Caunt 2006).

Much of the research involving ERK involves proliferation and growth factor stimulation and sustained expression of ERK is necessary for progression from G1 to S phase (Pouyssegur 2007). In cells lacking growth factor stimulation, ERK is sequestered in the cytoplasm by MEK (mitogen activated ERK specific kinase), a MAPKK (Fukuda 2000). Following activation, ERK localizes to the nucleus. Different ERK signal duration and localization yield different results, however the exact reason for this difference is not completely understood. Activated ERK accumulates in the nucleus, during mid G1 phase (Volmat 2001) and initiates transcription of immediate early genes in both mitogenic and non-mitogenic stimulation (Pouyssegur 2007).

\section{Dual Specificity Phosphatases (DUSPs)}

Phosphatase activity acts in opposition of upstream phosphorylation events in the MAPK cascade. As we had seen reduced pERK in other cell lines in response to DA agonists, we hypothesize that this change may be the result of increased phosphatase activity. The MAP Kinase Phosphatases, also known as DUSPs were a potential source of the increased phosphatase activity as this family of proteins regulates the MAPK family. DUSPs are a family of phosphatases comprised of a C-terminal catalytic domain with homology to $\mathrm{VH}-1$ phosphatase of vaccinia virus, a non-catalytic domain, which contains two regions with homology to cdc25 phosphatase, and a kinase interaction motif (KIM) (Keyse 2006). As MAPK activation requires dual phosphorylation on both threonine and tyrosine residues, removal of either phosphate results in reduced MAPK activity.

DUSPs reside in various cellular locations and maintain different specificity for MAPKs (Keyse 2006). They are divided into three groups, the nuclear inducible, cytosolic ERK specific and cytosolic nonspecific DUSPs. The nuclear DUSPs include MKP-1 (DUSP1), DUSP2, MKP-2 (DUSP4) and DUSP5. Of this group, DUSP5 is the only one specific to ERK. The others have activity toward all three MAPKs. The second and third group consists of cytosolic DUSPs, further divided by the specificity for MAPKs. The ERK specific DUSPs are DUSP 6 (MKP-3) and DUSPs 7 and 9 (MKP-4), while the JNK, p38 specific DUSPs are DUSP 8,10 and 16 (Owens and Keyse 2007; Zhou 2004). See Table 1.2 for specificities. 
Table 1.2. DUSP Family Members.

\begin{tabular}{cccc}
\hline Gene & MKP & $\begin{array}{c}\text { Subcellular } \\
\text { localization }\end{array}$ & Substrate preference \\
\hline DUSP1 & MKP-1 & Nuclear & JNK,p38, ERK \\
DUSP4 & MKP-2 & Nuclear & JNK,p38, ERK \\
DUSP2 & PAC-1 & Nuclear & ERK,p38 \\
DUSP5 & Hvh-3,b23 & Nuclear & ERK \\
DUSP6 & MKP-3 & Cytoplasmic & ERK \\
DUSP7 & MKP-X & Cytoplasmic & ERK \\
DUSP9 & MKP-4 & Cytoplasmic & ERK>p38 \\
\hline
\end{tabular}

Note: DUSPs studied belong to the MAP Kinase Phosphatase family and many have additional names. Listed are other commonly used names for these phosphatases. In this thesis DUSP names have been used. DUSPs are either cytoplasmic or nuclear inducible gene. Modified with permission. Owens DM, Keyse SM. (2007). Differential regulation of MAP kinase signalling by dual-specificity protein phosphatases. Oncogene. 26:320313.

\section{HYPOTHETICAL PATHWAY}

We hypothesize that the D2R mediated antiproliferative effect are the result of signaling through PLD. As shown in Figure 1.2 the agonist activation of results in the activation of PLD. We hypothesize that PA is metabolized to AA by either the action of cPLA2 or the sequential hydrolysis of PA by PAP and DAG lipase. We hypothesize that AA or a product of AA metabolism results in an increase of DUSP expression. The increase in DUSP activity reduces pERK and diminishes proliferation (Figure 1.2). D2R stimulation of PLD in GH4-121 cells, HEK (Senogles 2000) and SCLC cell lines (Senogles 2007) has been documented previously. 


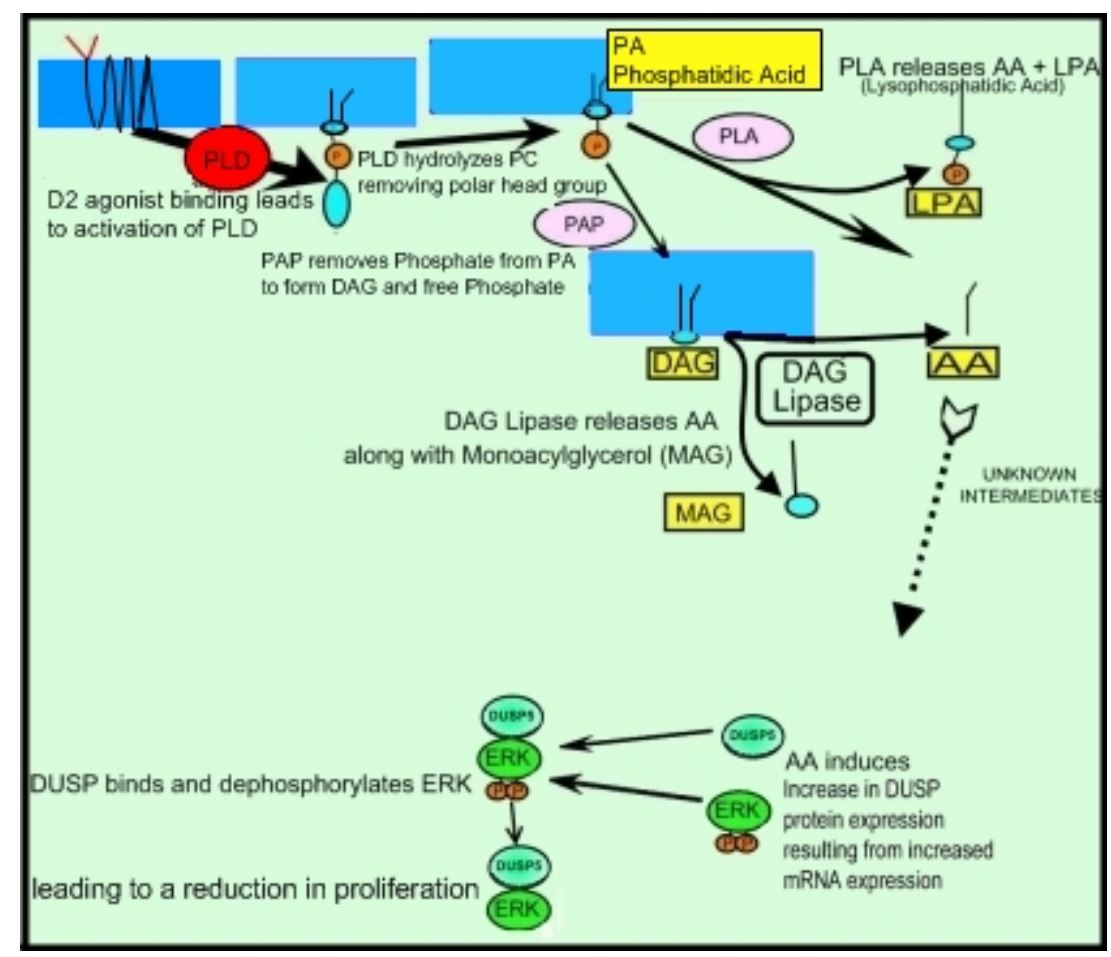

Figure 1.2. Hypothetical Pathway. D2R dopamine receptor induction of dual specificity phosphatases leading to reduced ERK 1/2 phosphorylation. 


\section{CHAPTER 2. MATERIALS AND METHODS}

\section{CELL CULTURE}

Human, SCLC Lung Cancer cells line, DMS 53 cells, (ATCC CRL-2062) are a tumor cell line established using cells from a 54 year old caucasian male. These cells are adherent cells which grow with epithelial-like morphology (Pettingil 1980). The DMS 53 Cell line was maintained Waymouth's MB 752/1 medium (Gibco) supplemented with $10 \%$ FBS (Atlanta Biologicals) and $50 \mathrm{ug} / \mathrm{ml}$ Gentimycin. Cell cultures were kept in 5\% $\mathrm{CO}_{2}$ at $37^{\circ} \mathrm{C}$.

Passaging of cells and preparation of cells for experiments was performed as follows. DMS 53 cells were grown to confluency in $2-75 \mathrm{~cm}^{2}$ flasks. Media was aspirated and cells were washed with $1 \mathrm{X}$ PBS. At this point, $1 \mathrm{~mL}$ of $0.05 \%$ Trypsin/EDTA was added to each flask and allowed to incubate until cells began to round up. Cells were suspended in complete media, split 14:1 into $2-6$ well plates for the experiment, discarding remaining cells and media. The other flask was split $2: 1$ into new $75 \mathrm{~cm}^{2}$ flasks. Following the 24 hour timeframe, experiment specific treatments were added.

\section{NPA TREATMENT AND CYQUANT NF CELLULAR PROLIFERATION ASSAY}

Cyquant NF cellular proliferation assay was carried out as recommended by manufacturer (Invitrogen). Cells from one $75 \mathrm{~cm}^{2}$ flask were Trypsinized and counted on a hemacytometer and serial diluted. Dilutions containing total cell numbers of 10000 , $5000,4000,3000,2000,1000,500,400,300,200,100$ cells/well were created in 100 $\mathrm{uL}$, giving six replicates per dilution. Each dilution was plated to a 96 well plate NPA (1 $\mu \mathrm{M}$ final) in dissolved in $10 \mu \mathrm{M} \mathrm{HCl}$, final concentration, or $10 \mu \mathrm{M} \mathrm{HCl}$ as a vehicle control were added giving three replications per condition and allowed to incubate overnight. Dye binding solution was added and the assay was carried out as recommended by manufacturer. Plates were excited at $485 \mathrm{~nm}$ and detection of fluorescence was carried out at $530 \mathrm{~nm}$.

\section{REAL TIME PCR}

\section{Concept}

The probe and primer combination in the LightCycler480 uses Fluorescence Resonance Energy Transfer technology for specificity, where primers specific for the gene in question give a large level of specificity. The probes, approximately five nucleotides in length, add another level of specificity as only in an area of cDNA where both primer and probe bind will result in fluorescence. A reporter and a quencher fluorophore are present 
on the probe. When intact, the reporter is quenched and no fluorescence occurs. When polymerase extends from the primer, the probe is removed one nucleotide at a time, separating the quencher from the reporter fluorophore, thus enabling fluorescence to be observed (Information from Roche Light Cycler Product Guide).

\section{Treatment and RNA Isolation}

Cells grown in 6 well cluster plates were grown to $70-80 \%$ and the media was aspirated. Cells were washed with $1 \mathrm{X}$ PBS and $3 \mathrm{~mL}$ of complete media was added. Cells were allowed to grow in this media for 24 hours in order to partially deplete catecholamines present in the serum. At this time, treatments were added for each individual experiment and incubated in media at $37^{\circ} \mathrm{C}$ in $5 \% \mathrm{CO}_{2}$. Following the completion of incubation in experimental conditions, cells were aspirated, washed, lysed and RNA extracted following the RNA II manufactures protocol (Clontech).

RNA was purified by Sodium Acetate and Ethanol Precipitation. Concentration of the RNA, A260/280 and A260/230 ratios were determined using the Nanodrop spectrophotometer. RNA integrity was determined using Agilent Bioanalyzer. RNA with 8.0 RNA Integrity Number (R.I.N.) or greater were retained, standardized using total RNA (1200 ng), reverse transcribed to cDNA using Transcriptor First Strand Synthesis Kit following the manufacturer's protocol. cDNA was added to Light Cycler 480 probes master (Roche) and Crossing points (CP) were determined using Taqman protocol on LightCycler 480.

\section{Primer Design}

Primers were designed using the Universal Probe Library found at https://www.rocheapplied-science.com/sis/rtpcr/upl/ezhome.html (Roche Diagnostics 1996-2010) (accessed February 29, 2008). Suggested primer sequences were compared to reported sequences for all eight DUSPs tested. If any primer had less than two mismatches in sequence, a separate set of primers was selected and verified. Primers were verified using a real time PCR standard curve. cDNA were serial diluted 10 fold, to give known relative concentrations. See Tables 2.1 and 2.2 for primer and probes used.

\section{Calculations}

Cycle number is inversely proportional to initial copy number of cDNA. Copy number must reach a threshold before fluorescence reaches logarithmic and linear phases. Each cycle doubles the concentration of cDNA, drawing closer to and eventually surpassing this threshold. The point at which fluorescence changes enter the logarithmic phase is defined as the crossing point (CP). Determining the exact point is difficult and requires some interpretation. In this assay, $\mathrm{CP}$ values were calculated from highest $2^{\text {nd }}$ derivative or inflection point of the curve. 
Table 2.1. Left Primer Information.

\begin{tabular}{|c|c|c|c|c|c|c|c|c|}
\hline \multirow[t]{2}{*}{ Gene } & \multirow[t]{2}{*}{ Accession \# } & \multirow[t]{2}{*}{ Amplicon } & \multirow[t]{2}{*}{$\begin{array}{l}\text { UPL Catalog } \\
\text { number }\end{array}$} & \multirow[t]{2}{*}{$\begin{array}{c}\text { Probe } \\
\#\end{array}$} & \multirow[t]{2}{*}{ Sequence $5^{\prime}$ to $3^{\prime}$} & \multirow[t]{2}{*}{ Length } & \multicolumn{2}{|c|}{$\begin{array}{l}\text { mRNA } \\
\text { position }\end{array}$} \\
\hline & & & & & & & Begin & End \\
\hline DUSP1 & NM_004417.2 & 64 & 04688643001 & 65 & $\begin{array}{c}\text { CGA GGC CAT TGA CTT CAT } \\
\text { AGA }\end{array}$ & 21 & 962 & 982 \\
\hline DUSP2 & NM_004418.2 & 91 & 04688040001 & 44 & $\begin{array}{c}\text { GAC TCC AGG GCT CCT GTC } \\
\text { TA }\end{array}$ & 20 & 569 & 588 \\
\hline DUSP3 & NM_004090.2 & 112 & 04687639001 & 30 & CGG ATC TAC GTG GGC AAC & 18 & 160 & 177 \\
\hline DUSP4 & NM_001394.5 & 87 & 04686900001 & 17 & $\begin{array}{c}\text { TGC ATC CCA GTG GAA GAT } \\
\text { AA }\end{array}$ & 20 & 1120 & 1139 \\
\hline DUSP5 & NM_004419.3 & 93 & 04685024001 & 5 & $\begin{array}{c}\text { ACA AAT GGA TCC CTG TGG } \\
\text { AA }\end{array}$ & 20 & 929 & 948 \\
\hline DUSP6 & NM_001946.2 & 112 & 04688651001 & 66 & $\begin{array}{l}\text { CGA CTG GAA CGA GAA TAC } \\
\text { GG }\end{array}$ & 20 & 789 & 808 \\
\hline DUSP7 & NM_001947.2 & 96 & 04685130001 & 14 & $\begin{array}{c}\text { CCC ATC TCT GAC CAC TGG } \\
\text { AG }\end{array}$ & 20 & 796 & 815 \\
\hline DUSP9 & NM_001395.1 & 103 & 04687949001 & 36 & $\begin{array}{c}\text { CAC TAC AAG CAG ATC CCC } \\
\text { ATC }\end{array}$ & 21 & 864 & 884 \\
\hline DUSP14 & NM_007036.2 & 81 & 04686959001 & 22 & $\begin{array}{c}\text { GCA CAC TGG ACT CTT GAG } \\
\text { GAA }\end{array}$ & 21 & 182 & 202 \\
\hline
\end{tabular}


Table 2.2. Right Primer Information.

\begin{tabular}{cccccc}
\hline Gene & Sequence 5' to 3' & MW & Length & \multicolumn{2}{c}{$\begin{array}{c}\text { mRNA } \\
\text { position }\end{array}$} \\
\cline { 5 - 6 } & & & & Begin & End \\
\hline DUSP1 & CTG GCA GTG GAC AAA CAC C & 5806.8 & 19 & 1007 & 1025 \\
DUSP2 & GCA GGT CTG ACG AGT GAC TG & 6198.1 & 20 & 640 & 659 \\
DUSP3 & TGT TGA CGT GCA TGA AGG A & 5907.9 & 19 & 253 & 271 \\
DUSP4 & GCA GTC CTT CAC GGC ATC & 5435.6 & 18 & 1189 & 1206 \\
DUSP5 & CCT TTT CCC TGA CAC AGT CAA & 6301.1 & 21 & 1001 & 1021 \\
DUSP6 & TTG GAA CTT ACT GAA GCC ACC T & 6694.4 & 22 & 879 & 900 \\
DUSP7 & CAG GAC ACC ACA CTT GG & 6062.0 & 20 & 872 & 891 \\
DUSP9 & CGC AGT TCT GGG ACA AGG & 5564.7 & 18 & 949 & 966 \\
DUSP14 & CGG CAA GAC CAG AGT GTT TT & 6157.0 & 20 & 243 & 262 \\
\hline
\end{tabular}


A grouping forms for each dilution of cDNA (Figure 2.1) with the full concentration on the left and each successive, 10 fold, dilution causes the shifting of the curve to the right approximately 3.32 cycles (Equation 2.1).

\section{$\log _{2} 10=3.32$}

Equation 2.1

This equation was the basis for the concentration curve. Determining the difference between the actual changes in molecules per cycle gives the efficiency of the reaction. As the real time PCR progresses, each cycle doubles the concentration of cDNA. Efficiency of this curve was measured based on the ability to double with each successive cycle. Efficient primers which double each cycle would change 3.32 cycles between each ten fold dilution. A linear concentration curve was generated, where the log of the concentration was plotted on the $\mathrm{x}$-axis and the corresponding $\mathrm{CP}$ value plotted on the $\mathrm{y}$ axis (Figure 1.3). Efficiency can be determined based on the reverse operation of Equation 2.1 as shown in Equation 2.2 (Bustin 2004).

$$
\text { Efficiency }=10^{(-1 / \text { slope })}-1
$$

Equation 2.2

Efficiency of this curve was measured based on the ability to double with each successive cycle. If the efficiency was below 1.8, alternative primers were selected. Figure 2.2 shows the standard curve for DUSP1.

Change in expression was determined using the ${ }^{\Delta \Delta} \mathrm{CT}$ method, where the slope of the efficiency curve was assumed to be two. Triplicate $\mathrm{CP}$ values were determined and averaged for the gene of interest and cyclophilin D standard for each cDNA. Delta CT was determined by subtracting the CP Value of Cyclophilin from that of each gene, giving every sample (one well from the six well plate) a Delta CT value. Because concentration doubles each cycle, subtracting $\mathrm{CP}$ values is the same as subtracting the logarithm of the concentration or dividing the concentrations. ${ }^{{ }^{\Delta}} \mathrm{CT}$ was then determined by subtracting the $\mathrm{CP}$ values determined from vehicle control from those of determined from cDNA derived from experimental conditions. If ${ }^{\Delta \Lambda} \mathrm{CT}$ was negative, meaning fold change was positive, Equation 2.3 was used to determine fold change (Bustin 2004).

$$
\text { Fold Change }=2^{(-\Delta \Delta C T)}-1
$$

Equation 2.3

In the cases where ${ }^{\Delta \Delta} \mathrm{CT}$ was positive, Equation 2.4 was used to determine mean fold expression change.

$$
\text { Fold Change }=-2^{(\Delta \Delta C T)}+1
$$

Equation 2.4

\section{Statistics}

Determination of ${ }^{\Delta \Delta} \mathrm{CT}$ statistic represents an $\mathrm{n}$ value of one. Thus, one cell culture well, containing the experimental treatment was compared to another well containing the 


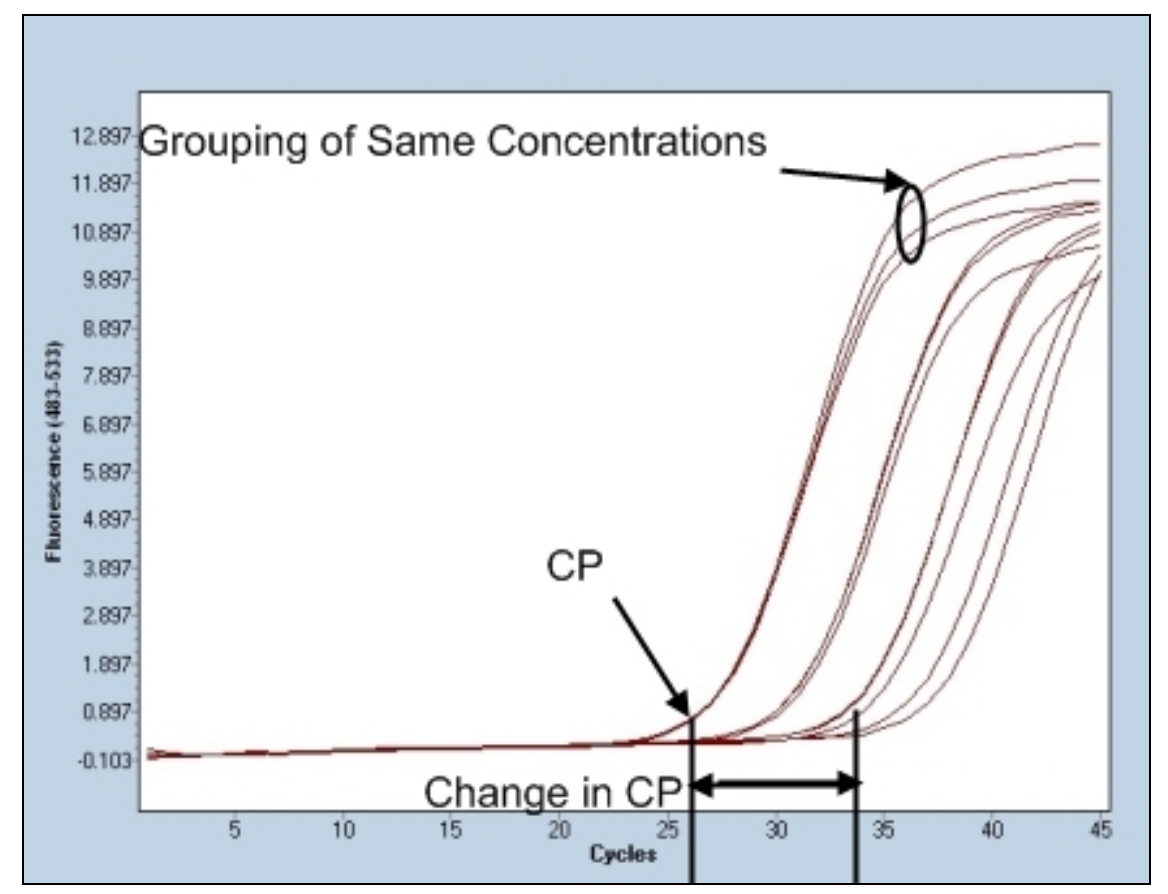

Figure 2.1. Real Time PCR Amplification Curves. Figure shows the fluorescence changes of DUSP1 concentration curve. Successive ten-fold serial dilutions of cDNA were made. Identical concentrations group together, giving similar Crossing point (CP) values. $\mathrm{CP}$ value is the theoretical point where fluorescence leaves the baseline, but is determined by the point of highest $2^{\text {nd }}$ derivative. Change in expression is proportional to the change in $\mathrm{CP}$ values.

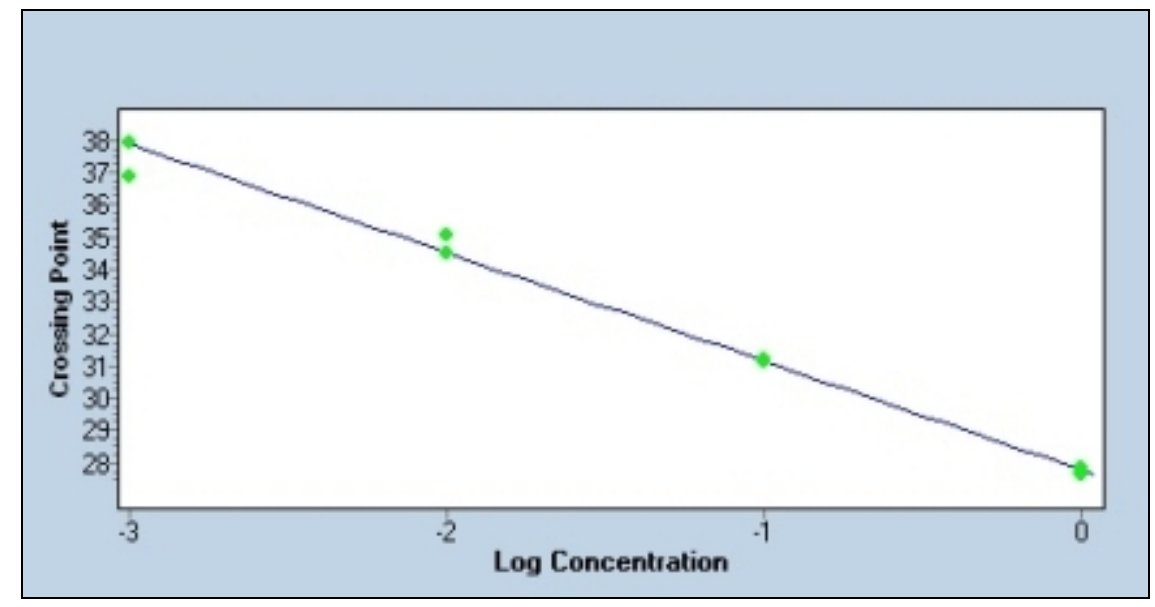

Figure 2.2. Standard Curve for DUSP1. This is an example of the curves used to determine efficiency of primers in real time PCR. 
control for an $n$ value of one. One set of RNA and subsequently one cDNA was generated from each well, thus each number (n) was a separate experiment. In order to prevent a batch effect, real time PCR was performed over the course of several days. Each cDNA from treated cells was only compared to those of controls generated on the same day, however. Hypothesis tests where NPA was compared to vehicle were performed to obtain fold change data. A value of zero represented the null hypothesis. An unpaired students t-test was performed comparing fold change over vehicle to the null hypothesis of zero change. For inhibition experiments (AA, Ethanol and ETYA) hypothesis testing was carried out using a two-tailed unpaired t-test.

\section{Selection of Cyclophilin D as a Reference Gene}

Prior to any real time PCR analysis, cells were treated with appropriate concentration of drugs of interest. For example $1 \mu \mathrm{M}$ NPA, $100 \mu \mathrm{M}$ NPA or Vehicle was used in NPA experiment. Three individual experiments were performed and RNA was extracted and reverse transcribed to cDNA. As an effective standard, we sought out a gene of which expression did not change following application of drugs of interest. Real time PCR was performed in triplicate for each cDNA using primers for six different human housekeeping genes including Cyclophilin D, beta actin, beta 2 microglobulin, beta glucuronidase, TATA box binding protein, transferin receptor. Expression of each gene was compared to concentration of the drugs of interest and correlation coefficients and $\mathrm{R}$ squared values were calculated for each gene. None of the housekeeping genes analyzed had greater than $0.15 \mathrm{R}$ squared value. The Cyclophilin $\mathrm{D}$ gene at $\mathrm{R}$ squared equal to 0.04 was the lowest of any of these genes, indicating that this gene changed very little in response to drug addition. Thus, cyclophilin D was selected as the reference gene used to standardize the Real time PCR experiments.

\section{WESTERN BLOT}

DMS 53 cells were split into $2-6$ well plates, plated at a density of $10^{5}$ cells/well and grown to $70-80 \%$ confluency at which point the media was aspirated, cells were washed and complete media was added. Drugs of interest were added and cells were lysed. At the time of lysis, cells were aspirated, washed with PBS. Cells were kept on ice, where they were lysed using with $600 \mathrm{uL}$ ice cold RIPA buffer $(25 \mathrm{mM}$ Tris-HCl pH 7.6, 150 $\mathrm{mM} \mathrm{NaCl}, 1 \% \mathrm{NP} 40,1 \%$ sodium deoxycholate, $0.1 \%$ SDS), containing protease inhibitor cocktail (P8340 Sigma, containing AEBSF for serine proteases, Aprotinin for serine proteases, Bestatin hydrochloride for aminopeptidases, E-64 for cysteine proteases, Leupeptine hemisulfate salt for serine and cysteine proteases and Pepstatin A for acid proteases) for $15 \mathrm{~min}$. Following this incubation, lysates were passed several times through a 21 gauge needle and once again placed on ice for 30 minutes. Lysates were pelleted via centrifugation at $10000 \mathrm{X}$ G. Supernatents were removed and stored overnight at $-20^{\circ} \mathrm{C}$ and the pellets were discarded. 
Protein concentrations were determined using the Bradford method (1976) with Bradford Reagent (BioRad) using Bovine Serum Albumin as the standard. Samples were boiled 5 min and mixed with 2X sample buffer (Laemmli 1970). Routinely a total protein concentration of $50 \mathrm{ug}$ was loaded and subjected to electrophoresis through a $12 \%$ SDSPAGE (Laemmli 1970) gel at $100 \mathrm{~V}$. Proteins were transferred to nitrocellulose membrane by blotting at $110 \mathrm{~V}$ for $1 \mathrm{hr}$. Membranes were blocked overnight in Blotto A (5\% nonfat dry milk in, $0.01 \%$ Tween 20$)$. Membranes were incubated in primary antibody for 1 hour at ambient temperature, washed 3 X 15 minutes in PBS-T (1 X PBS $+0.01 \%$ Tween 20$)$. Primary antibody dilution used were Rabbit IgG polyclonal antiDUSP5 (281-295) (sigma \# D8819) 1:1000 or anti-pERK at 1:1500 (Abcam \#ab65142), anti-Beta Actin mouse monoclonal IgM (Oncogene Sciences) at 1:1200. The secondary Ab used were Goat anti rabbit 1:1000) Horseradish Peroxidase (HRP) Conjugate (Biorad) for DUSP5 and pERK. For actin a secondary HRP conjugate (Oncogene Sciences \#JA1200) was used (1:1500). Membranes were visualized using Enhanced Chemiluminescence Substrate (Western Lightning). 


\section{CHAPTER 3. RESULTS}

\section{D2R DOPAMINE RECEPTOR MEDIATED ANTIPROLIFERATION IN DMS 53 CELLS}

\section{Experimental Reasoning}

The D2R mediated antiproliferative effects have been well established in D2R transfected lactotroph cells, HEK cells and native NCI-H69 SCLC cell lines. NPA addition to all of these cultures consistently results in reductions in $\left[{ }^{3} \mathrm{H}\right]$ thymidine incorporation and concomitant reductions in cell numbers. We chose to characterize DMS 53 cells, which form a monolayer as opposed to NCI-H69 cells, which are suspension cells. We needed to confirm that D2R stimulation indeed resulted in the antiproliferative pathway in DMS 53 cells. We assessed changes in proliferation following addition of NPA, a D2R agonist, using the Cyquant Cell Proliferation Assay (Invitrogen).

\section{Results of D2R Mediated Antiproliferation}

The proliferation assay confirmed preliminary results that NPA treatment resulted in a reduction in proliferation and cell number (Figure 3.1). The Cyquant assay measures the DNA present in cells and is used as a reliable measure of cell number. Results of this assay revealed a $27 \%$ reduction in proliferation $(\mathrm{p}<0.001)$ with $1 \mu \mathrm{M}$ NPA addition overnight at 10000 cells plated (Figure 3.1). Significant reductions in fluorescence of $36 \%, 14 \%$ and $31 \%$ were witnessed when $5000(\mathrm{p}<0.001), 4000(\mathrm{p}<0.05)$ and 2000 $(\mathrm{p}<0.05)$ cells were plated respectively. Mean fluorescence levels decreased in cells treated with NPA. As shown, the relative fluorescence changed with cell number, which shows this assay is linear over a large range of cell numbers $(500-10,000)$ used in this experiment. The reduction in proliferation shown in this assay confirmed results observed in our laboratory, using other methods such as $\left[{ }^{3} \mathrm{H}\right]$ thymidine incorporation or counting of cell number after Trypan blue exclusion staining. Overall, this experiment demonstrated that the DMS 53 cells, a SCLC cell line, responds to treatment with NPA, a $\mathrm{D} 2 \mathrm{R}$ agonist by decreasing proliferation.

The results seen here demonstrate that NPA a DA agonist leads to reduction in proliferation in the SCLC cell line, DMS53. The $27 \%$ reduction in proliferation was modest; however it was performed in a relatively short time period of 4 hours. Changes in proliferation were confirmed with changes in cell count performed with a hemacytometer (Data not shown). The reduction in proliferation generated in this assay is routinely less than that observed with $\left[{ }^{3} \mathrm{H}\right]$ thymidine incorporation (about 50\%) in our laboratory (Senogles unpublished). 


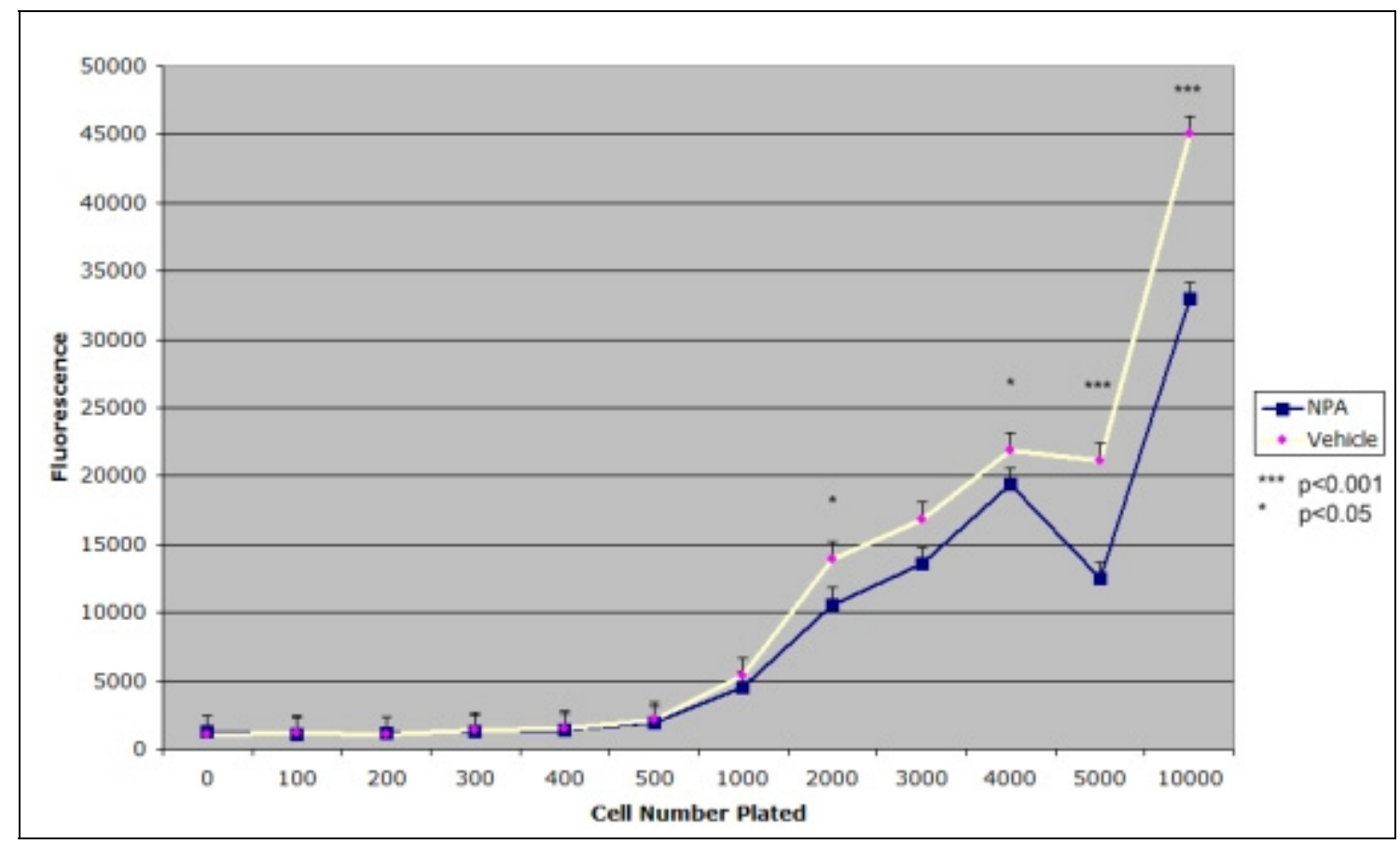

Figure 3.1. NPA Inhibition of Proliferation in DMS 53 Cells. Total cell numbers were plated as indicated above and treated in the presence (squares) or absence of NPA (circles) overnight prior to the detection of fluorescence.

\section{Discussion of D2R Mediated Antiproliferation}

The Cyquant cell proliferation assay uses a permeant Cyquant GF dye. The fluorescent dye is enhanced when binding to cellular nucleic acids and incorporates to DNA when cells are dividing. The changes in cell number correlate well with those seen in $\left[{ }^{3} \mathrm{H}\right]$ thymidine incorporation assays (Jones 2001). As a result, changes in fluorescence should closely correlate with changes in proliferation, as this method is monitoring DNA content and hence cell number.

NCI-1876 cells were also assayed and showed no significant changes in proliferation or signaling in response to NPA as revealed by Cyquant assay (data not shown). This is an appropriate negative control for experiments as these cells express D2R dopamine receptors but are refractory to signaling by DA agonists (Senogles, unpublished observations).

Several methods could have been employed in order to generate greater changes in proliferation. The assay might have been optimized by determining the time of maximum change in proliferation, by determining fluorescence at 12 hours, 18 hours, 24 hours and 36 hours. In addition, cell synchronization might augment the changes in proliferation. Optimization of the effects likely would evoke similar changes to those seen in other DA responsive cells and tissues such as anterior pituitary cells (Pawlikowski 1978) primary 
lactotroph cultures (Senogles 1994; Stepien 1978) and SCLC cells and tissues (Ishibashi 1994; Senogles 2007).

Previous results from this laboratory suggest that this effect is a D2R specific phenomenon. NPA as a DA agonist has a higher specificity for D2R like receptors, but does not differentiate well between D2R and D3 isoforms. SCLC cell lines have been assayed using RT PCR using probes specific for DA receptor subtypes. In NCI-H69 cells (Senogles 2007) and DMS 53 (Senogles unpublished) cell lines, both forms of D2R receptors were present, but other D2R like receptors, such as D3 were not detectable.

\section{D2R RECEPTOR STIMULATED REDUCTION OF PERK IMMUNOREACTIVITY IN DMS 53 CELLS}

\section{Experimental Reasoning}

Treatment of lactotroph cells with a D2R agonist has been reported result in a reduction of TRH stimulated pERK (Banihashemi and Albert 2002). In an SCLC cell line, NCI H69, our laboratory has demonstrated that treatment with NPA will result in a reduction of pERK immunoreactivity and in ERK kinase activity (Senogles, unpublished observations). These results have yet to be confirmed in the DMS 53 cell line. As a result, we wanted to investigate changes in ERK phosphorylation in these cells before and after treatment with NPA. Cells were treated with $1 \mu \mathrm{M} \mathrm{NPA}$ in $10 \mu \mathrm{M} \mathrm{HCl}$ or with vehicle containing a final concentration of $10 \mu \mathrm{M} \mathrm{HCl}$ and incubated for four hours prior to lysis.

\section{Results of pERK Western Blot Analysis}

As shown in Figure 3.2, treatment with NPA decreased the total amount of phosphorylated ERK in DMS 53 cells. This result is in agreement with results previously observed GH4ZR7 in NCI-H69 cells (Senogles unpublished observations). Stripping of the blot followed by re-probing with an antibody to actin showed no change in actin expression. The phosphorylation of ERK was changed over 4 hours, but the protein expression probably did not change as actin protein levels were constant.

\section{Discussion of pERK Western Blot Analysis}

The results here demonstrate pERK immunoreactivity changed following the addition of NPA and suggest that pERK levels decrease in response to treatment with D2R agonist. Actin was used as a loading control for this blot, and the amount of actin did not change over time. However, we remain uncertain that DA agonist addition was not decreasing total ERK levels as well. Typically, pERK blots are reprobed for total ERK using a panERK antibody which would determine total ERK. 


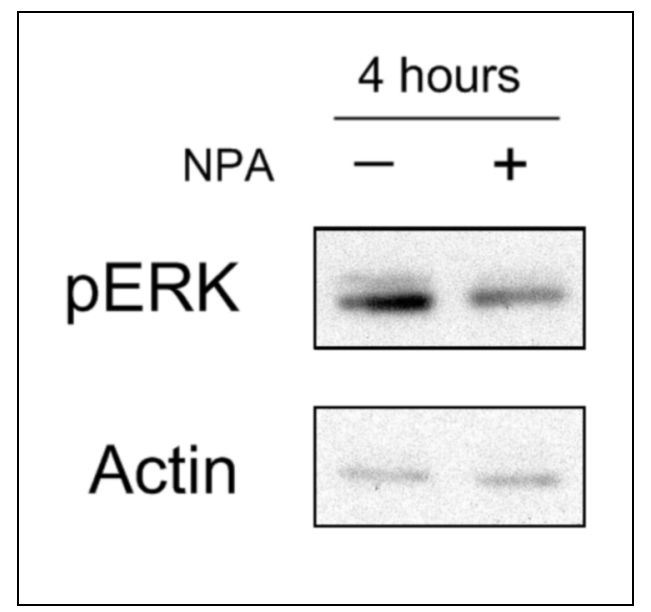

Figure 3.2. pERK Immunoreactivity following NPA Treatment. DMS 53 cells were treated with $1 \mu \mathrm{M}$ NPA for four hours. Cells were harvested and lysates were subjected to SDS-PAGE and Western Blot was performed using a polyclonal anti-pERK antibody. The blot was visualized with enhanced chemiluminescence.

However, we should still investigate an exact timeline to determine the point of maximum change in pERK. In NCI-H69 cells pERK levels decrease with time of NPA treatment (Senogles unpublished observations). This result suggests either a reduction of MEK activity or an increase in phosphatase activity. Our laboratory has demonstrated that MEK kinase activity does not change in response to DA agonists (Senogles unpublished observations). Thus, the reduction in phosphorylation is likely the result of greater phosphatase activity. We chose to investigate the potential role of phosphatases in this effect. Members of the DUSP family exhibit varied specificities of MAPKs and ERK specifically. We chose to identify members of this family through real time PCR. Real time PCR analysis would enable us to quickly identify which DUSP changed with DA agonist addition.

\section{SIGNIFICANT ELEVATION OF DUSP1, DUSP4 AND DUSP5 EXPRESSION FOLLOWING NPA TREATMENT}

\section{Experimental Reasoning}

Unpublished results from our laboratory suggested that ERK phosphorylation and kinase activity was decreased in response to D2R agonist treatment (Senogles, unpublished observations). We wanted to determine what was leading to these changes. The laboratory had previously demonstrated that the reduction in ERK phosphorylation was not due to decreased MEK activity which would result in lower ERK phosphorylation (Senogles unpublished). In vitro kinase assays using a recombinant ERK as substrate, demonstrated that treatment of cells with NPA did not result in a decrease of MEK 
activity (Senogles, unpublished observations). As ERK phosphorylation can be regulated either by upstream kinases (MEK) or downstream phosphatases, we chose to investigate the involvement phosphatases in this phenomenon. Our cells are growing in media supplemented with fetal bovine serum. As a result, the cells are actively proliferating in response to growth factors present in the sera. Our hypothesis is that NPA treatment turns on a signaling cascade which results in the change of expression or activity of a phosphatase which results in ERK becoming dephosphorylated and leading to a decrease in proliferation. In our hypothesis, members of the DUSP family of proteins are potentially important regulators of ERK phosphorylation and we have chosen to investigate the effect of NPA on DUSP expression in DMS 53 cells.

As we showed in our hypothetical pathway in Figure 1.2, AA may play a role in the antiproliferative effect by D2R agonists. As summarized previously, agonist treatment of D2Rs transfected CHO cells resulted in release of AA (Piomelli 1991). In addition, there is evidence from another laboratory which is relevant. In Vascular Smooth muscle cells, AA stimulates increases in DUSP1 expression with subsequent changes in protein levels (Metzler 1996). This increase in DUSP1 results in a concomitant reduction of proliferation. It is our hypothsis that D2R stimulated signaling may result in AA release which results in changes in DUSP expression.

Thus, we wanted to determine the expression changes of several DUSP genes following D2R receptor stimulation with NPA in the SCLC cell line, DMS 53. Gene expression data for eight different DUSPs were evaluated using real time PCR analysis. DMS 53 cells were treated with NPA for the following intervals: $1 \mathrm{hr}, 2$ hrs or 6 hrs. Controls were treated with vehicle: $10 \mu \mathrm{M} \mathrm{HCl}$. See Materials and Methods for details of RNA extraction, reverse transcription and discussion of real time PCR.

\section{Result of NPA Treatment Addition to DMS 53 Cells}

\section{DUSP1}

A comparison of vehicle and NPA treated DMS 53 cells revealed significant increases in DUSP1 (MKP-1) at $1 \mathrm{hr}, 2 \mathrm{hrs}$ and $6 \mathrm{hrs}$ (Figure 3.3). All of the real time PCR data were standardized using cyclophilin as a control gene. We had shown that cyclophilin was the least variable of all of the housekeeping genes. At $1 \mathrm{hr}, 1 \mu \mathrm{M}$ NPA treatment led to 0.18 fold increase $(n=18, p<0.01)$ of DUSP1. At 2 hrs, DUSP1 expression was elevated 0.57 fold compared to vehicle $(n=60, p<0.001)$, while at $6 \mathrm{hrs}$ change in expression was at the highest with a 0.63 fold increase $(n=49, p<0.001)$ (Figure 3.3). These results demonstrated a time dependent increase in DUSP1 expression following NPA treatment.

\section{DUSP4}

NPA treatment treatment brought about a marginal reduction in DUSP4 (0.16 fold) at 1 $\mathrm{hr}(\mathrm{n}=13, \mathrm{p}<0.05)$. However, at later time points and with larger sample sizes, increases were seen. DUSP4 expression increased with NPA treatment 0.11 fold at $2 \mathrm{hrs}(\mathrm{n}=70$, 


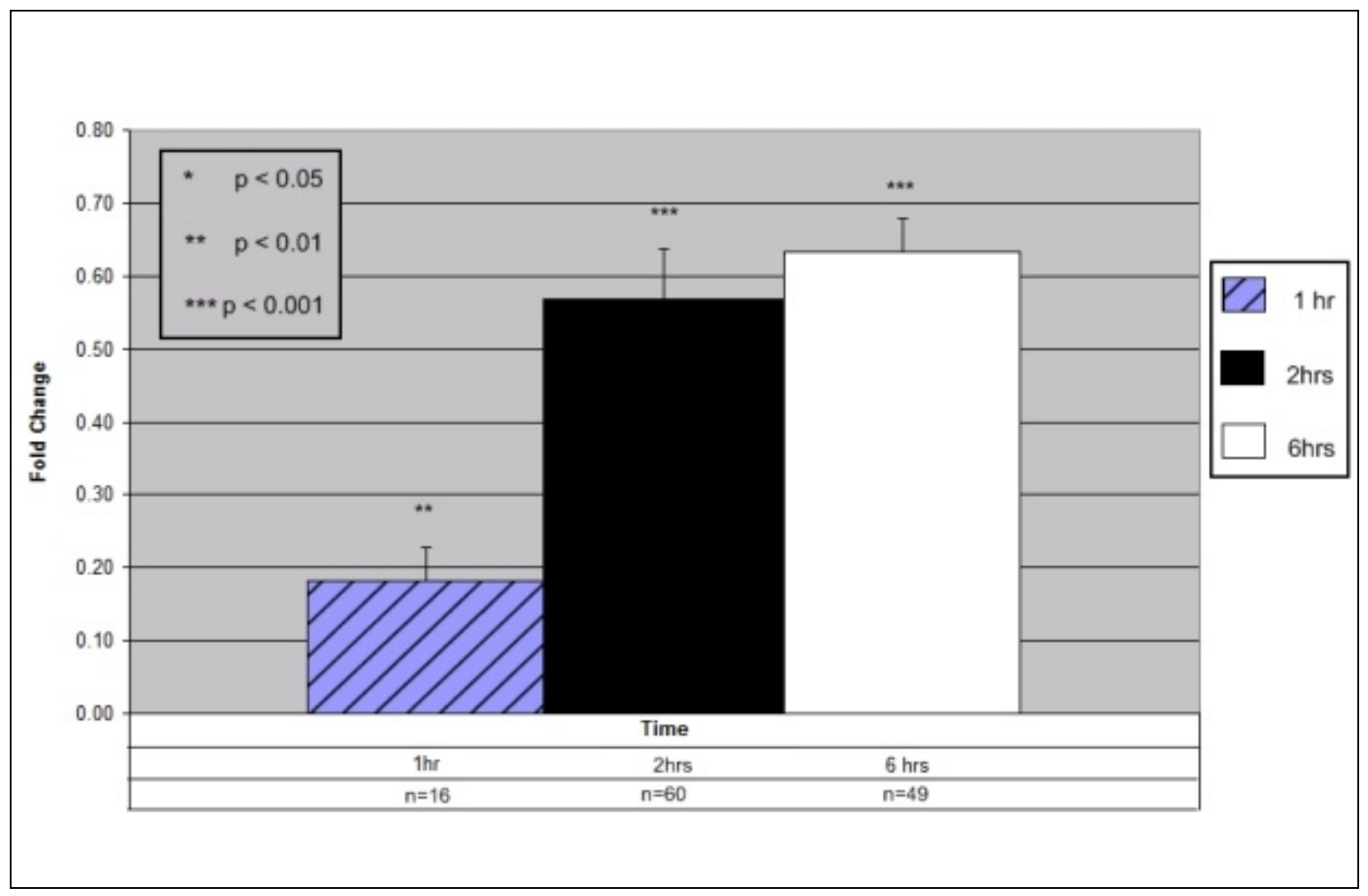

Figure 3.3. Real Time PCR Analysis of DUSP1 Expression in DMS 53 Cells following Addition of NPA, a D2R Agonist. All samples were standardized using cyclophilin D. The fold change is calculating taking the NPA treated samples divided by the vehicle. A baseline of zero indicates no change compared to vehicle control. 
$\mathrm{p}<0.001$ ) and was at a maximum of 0.17 fold increase at 6 hrs (Figure 3.4).

\section{DUSP5}

Significant increases in DUSP5 were seen at $2 \mathrm{hrs}$ with a 0.26 fold increase over vehicle $(\mathrm{n}=66, \mathrm{p}<0.001)$ following D2R stimulation with NPA (Figure 3.5). DUSP5 levels increased even more at $6 \mathrm{hrs}$, reaching a 0.46 fold increase $(n=63, p<0.001)$. These results demonstrate a significant time dependent increase in DUSP 5 expression after NPA treatment.

\section{DUSP2}

DUSP2 (Figure 3.6) demonstrated small changes in expression. While changes were evident, these small changes appeared to achieve significance due to repetition.

Other DUSP Family Members

Other DUSP family members were evaluated for changes in expression following NPA treatment of DMS 53 cells. Shown (Figure 3.7) are the results for DUSP 3, 6, 7, 9 and 14 after treatment for 1, 2 or 6 hours with NPA. For the sake of comparison, the previously shown results for DUSP 2 are displayed. The expression of DUSP 3, 6, 7 and 9 does not rise over 0.2 fold compared to vehicle controls. While these measurements have significance due to the large number of repetitions, the changes observed are not large. DUSP 14 showed changes in expression with NPA treatment at 2 and 6 hours which were over 0.3 compared to vehicle control.

\section{Discussion of NPA Addition to DMS 53 Cells}

Real time PCR revealed statistically relevant increases in DUSPs 1, 2, 4, 5, 6 and 14. We believe some of the small variations observed (between 0.2 to -0.2 ) represent the experimental variation caused by evaluation of real time PCR. At this level of change, it is difficult to determine whether any actual change in mRNA is occurring. While statistical significance was reached for DUSPs 2, 4, 6, 14 the minor levels of change are close to those seen in cases of statistical variation. The reliability and biological significance of the changes seen in these genes is questionable. In order to maximize the reliability of this assay, the experiments were performed on multiple days.

Increases in DUSP1 and DUSP5 were evident as early as 2 hours and remained elevated until 6 hours. These increases tripled the estimated experimental variation and the changes in these two genes occurred consistently.

While statistically significant, the biological relevance of these minor changes in mRNA are in question. Do these minimal changes represent actual changes in genes expression? Are the changes large enough to result in subsequent changes in protein levels? The increases in mRNA seen were relatively minor and increased transcription may be the 


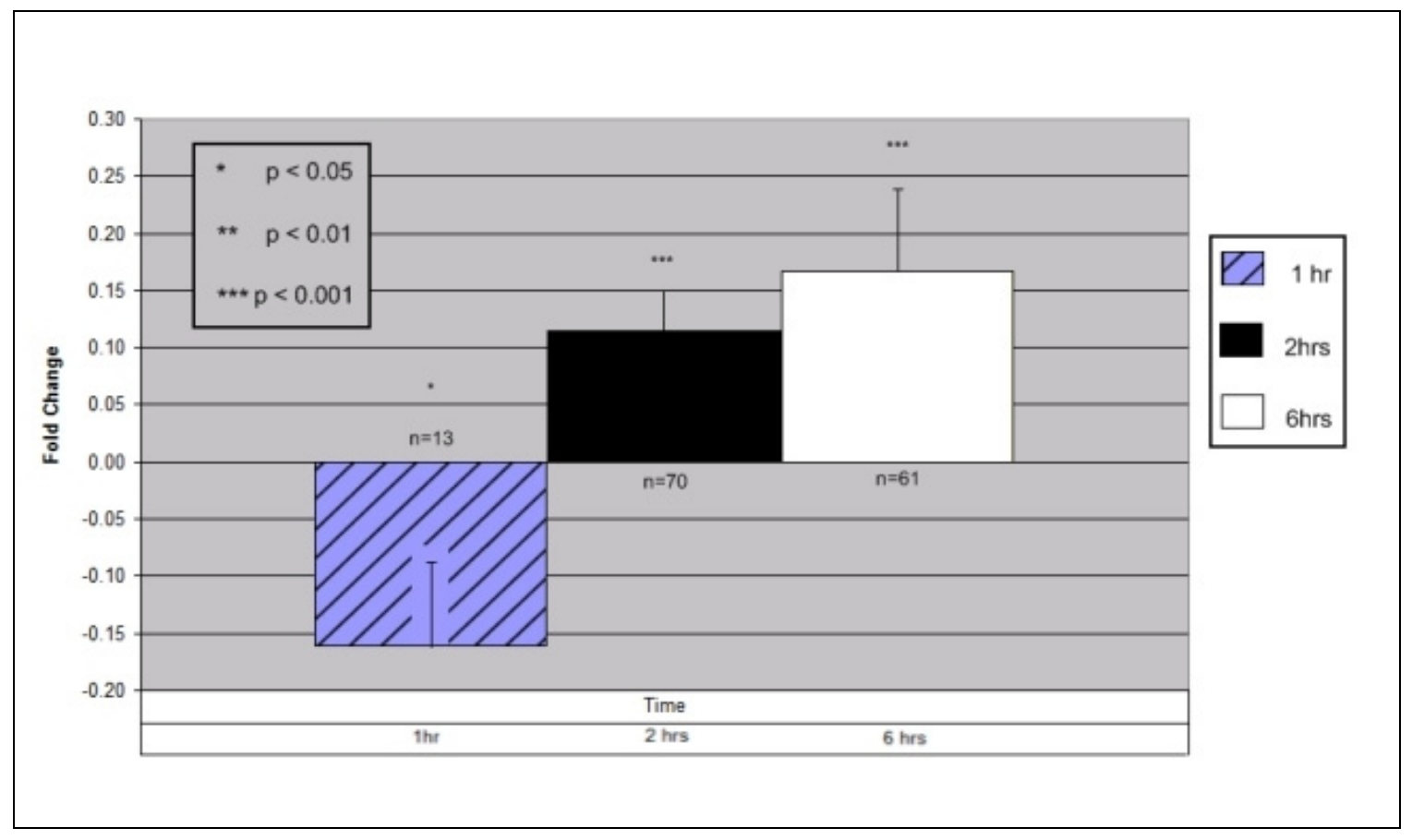

Figure 3.4. Real Time PCR Analysis of DUSP4 in DMS 53 Cells following Treatment with NPA. All samples were standardized using cyclophilin D. The fold change is calculated by taking the NPA treated samples divided by the. A baseline of zero indicates no change compared to vehicle control. 


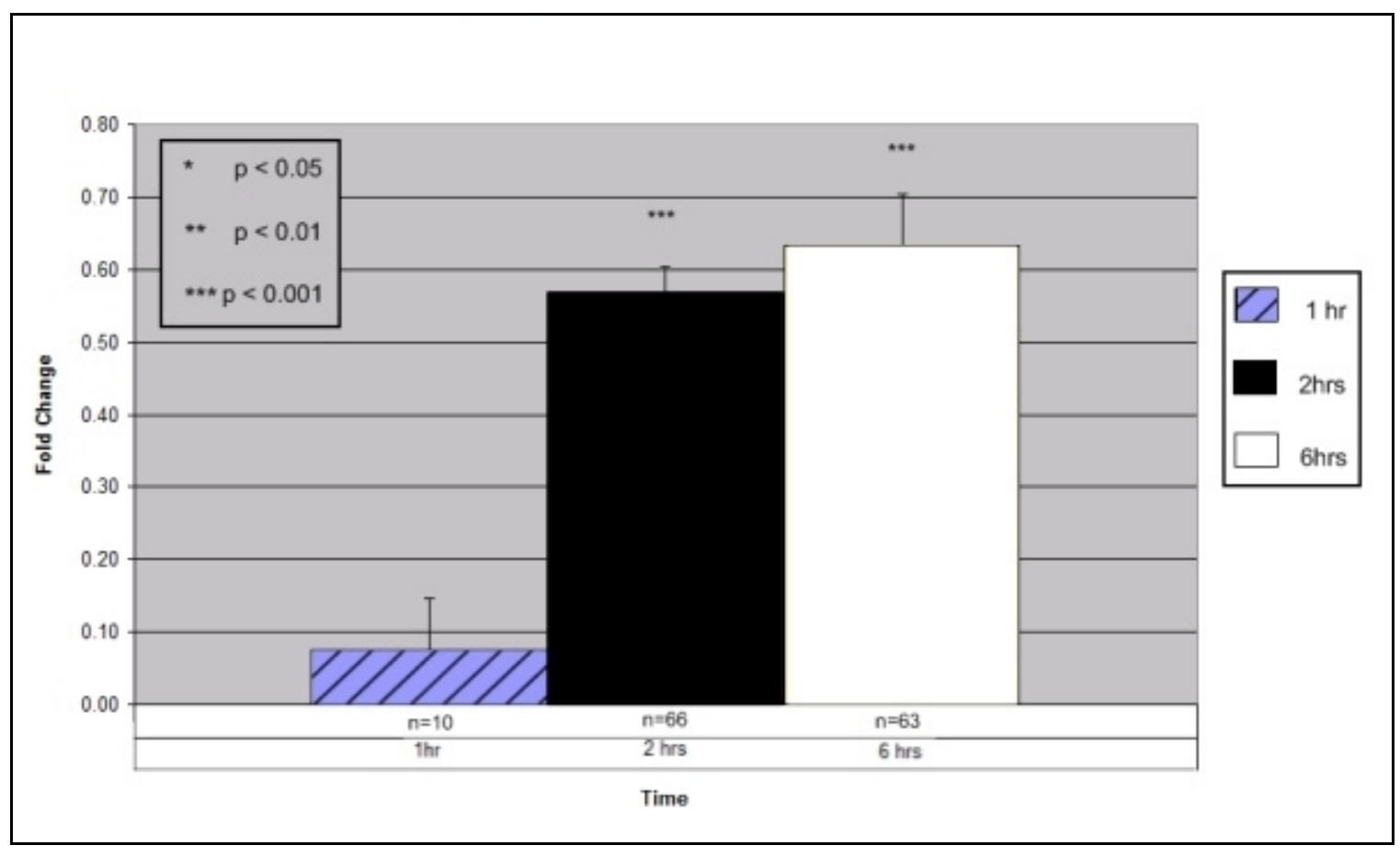

Figure 3.5. Real Time PCR Analysis of DUSP5 in DMS 53 Cells following

Treatment with NPA. All samples were standardized using cyclophilin D. The fold change is calculated by taking the NPA treated samples divided by the vehicle. A baseline of zero indicates no change compared to vehicle control. 


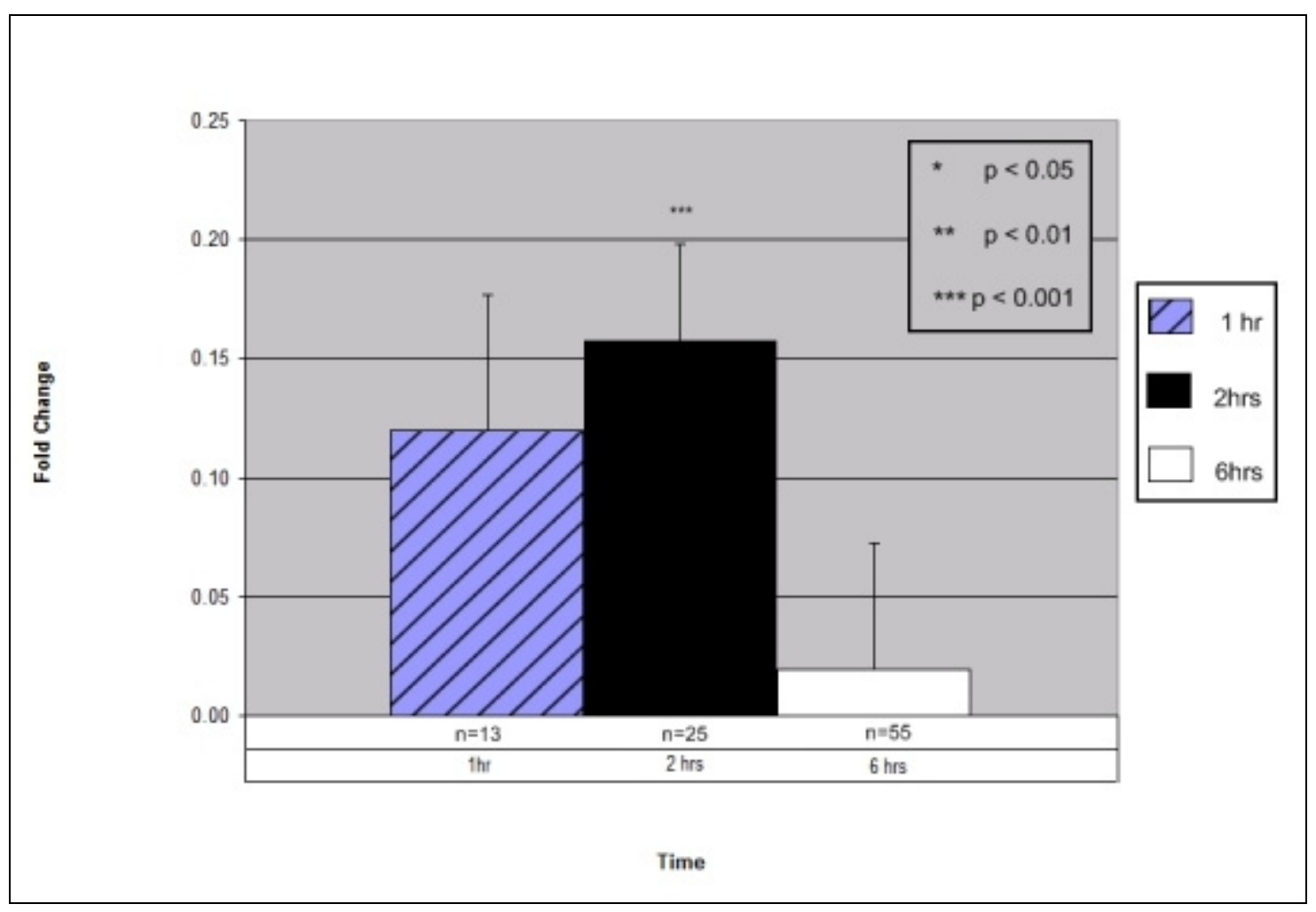

Figure 3.6. Real Time PCR Analysis of DUSP2 in DMS 53 Cells following Treatment with NPA. All samples were standardized using cyclophilin D. The fold change is calculated by taking the NPA treated samples divided by the vehicle. A baseline of zero indicates no change compared to vehicle control. 


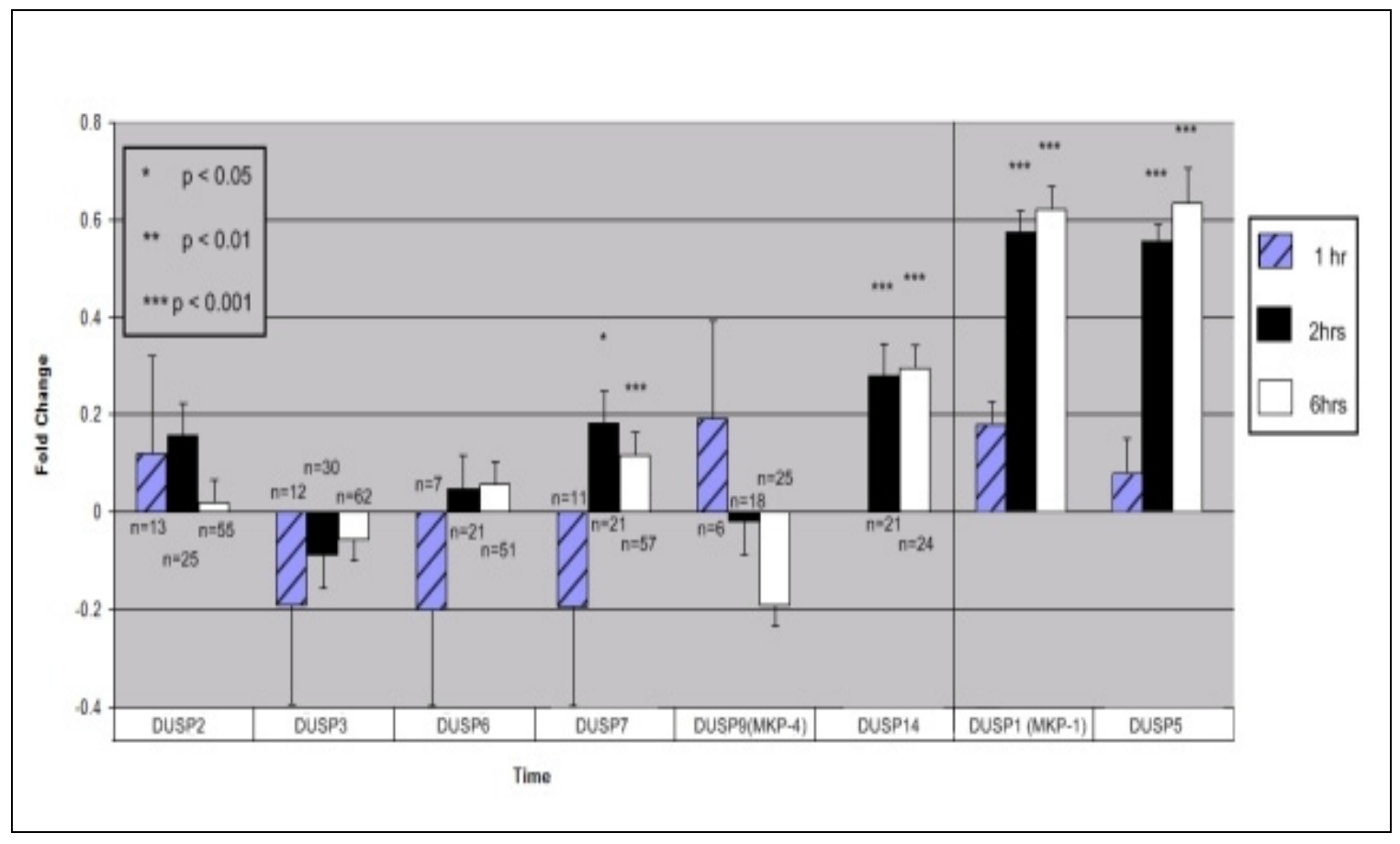

Figure 3.7. Real Time PCR Analysis of DUSP Family Members in DMS 53 Cells following NPA Treatment. All samples were standardized using cyclophilin D. The fold change is calculated by taking the NPA treated samples divided by the vehicle. A baseline of zero indicates no change compared to vehicle control. The data for DUSP1 and DUSP5 (Figure 3.3 and 3.5 are shown again for a comparison). 
source. Instead, decreased degradation of mRNA may lead to these changes. In order to determine which effect is occurring, NPA induction while halting transcription could be analyzed. If halting transcription inhibits the NPA induction of the DUSP genes, the induction is likely occurring through increased transcription. Three of the genes increased in this assay, DUSP1, DUSP4 and DUSP5, are all nuclear-inducible genes. While the changes are modest, the fact that primarily putative inducible DUSPs are involved suggests that actual increased expression of these genes is more likely. If degradation was occurring, it would possibly affect both classes of genes equally.

In order to determine if subsequently protein levels were being increased, we wanted to assess these changes through Western Blot. Real time PCR results revealed the greatest increases of mRNA in DUSP1 and DUSP5, as result we decided to investigate these genes. Preliminary results from DUSP4 (MKP-2) western blots showed DA dependent increases (Senogles unpublished). This information, together with real time PCR results for DUSP4, led us to further investigate this gene as well. NPA treatments for these all three of these genes, which were used as controls in later real time PCR experiments, consistently resulted in increases in mRNA.

\section{NPA INCREASES IN DUSP5 AS REVEALED BY WESTERN BLOT}

\section{Experimental Reasoning}

As we had observed increased mRNA expression for DUSP1, DUSP4 and DUSP5 and we wanted to determine if protein levels were also changing. Previously, western blots were performed, which had demonstrated increases in MKP-2 (DUSP4), but none for MKP-1 (DUSP1) (Senogles unpublished). Due to technical difficulties with commercially available antibodies and time constraints, we were unable to evaluate all of these proteins for this thesis by Western Blot analysis. Due to the consistent changes in DUSP5 expression after NPA treatment we chose to investigate changes in DUSP5 protein expression. DUSP5 also has a high specificity of ERK and overexpression has been known to reduce ERK phosphorylation (Owens and Keyse 2007). DUSP5 anchors ERK in the nucleus, maintaining ERK in a dephosphorylated state and leads to a reduction in proliferation (Keyse 2005).

\section{Result of DUSP5 Western Blot Analysis}

NPA stimulation of DMS 53 with $1 \mu \mathrm{M}$ NPA for 2 hours and 6 hours brought upon increases in DUSP5 protein over $10 \mu \mathrm{M} \mathrm{HCl}$ as a vehicle control, as revealed by western blot analysis with a DUSP5 specific antibody (Figure 3.8). These changes were reproducible and cell types specific. Marked increases in DUSP5 were observed compared to $10 \mu \mathrm{M} \mathrm{HCl}$ in DMS 53 cells, but not SCLC NCI-1876 cells (Figure 3.9). NCI-1876 cells are unresponsive to the effect of DA and are a negative control (Senogles unpublished observations). 


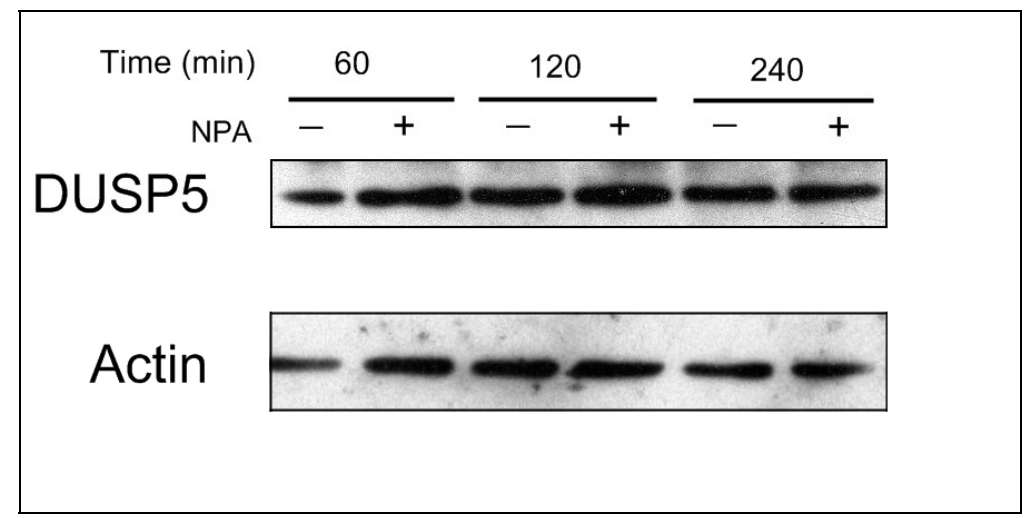

Figure 3.8. Western Blot of DUSP5 Protein Expression Time Course after

Treatment with NPA. DMS 53 cells were treated in the presence and absence of $1 \mu \mathrm{M}$ NPA for the times indicated. Lysates were prepared from these cells and subjected to SDS-PAGE and Western blotting. The blots were visualized with Anti-DUSP 5 antibody and chemiluminescence. The blot was stripped and reprobed with anti-actin antibody.

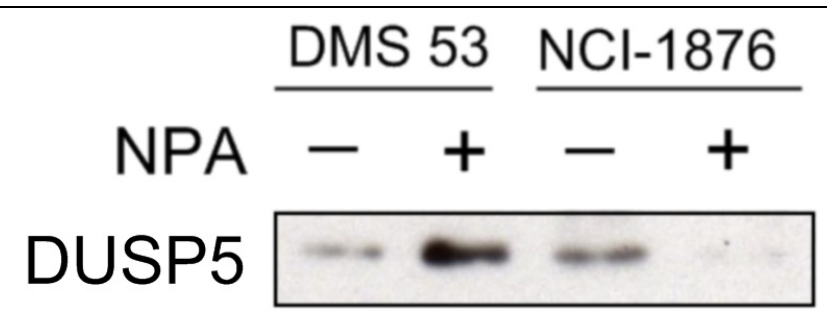

Figure 3.9. Western Blotting of NPA Induction of DUSP5 Using NCI-1876 Cells as a Negative Control. DMS 53 cells and NCI-1876 cells were treated with $1 \mu \mathrm{M}$ NPA for 2 hours. Lysates were prepared from these cells and subjected to SDS-PAGE and Western blotting. The blots were visualized with Anti-DUSP 5 antibody and chemiluminescence. 


\section{Discussion of DUSP5 Western Blot Analysis}

The expression of DUSP5 proteins increased the largest at two hours (Figure 3.8) with more modest increases observed at 1 hours and 4 hours. At 2 hours the intensity density of the Actin control also remains consistent. As expected, no increase was seen in NCI1876 cells, which do not respond to DA by reducing proliferation or signaling to adenylyl cyclase or PLD. Protein concentrations levels were standardized prior to electrophoresis and western blot analysis to minimize variation.

Other western blots of Actin protein suggest that NPA does not stimulate change in actin. However, a control where the DUSP5 blot in Figure 3.9 was stripped and reprobed for Actin or other housekeeping protein is necessary for confirmation.

We were still left with questions about the mechanisms leading to the increase in DUSP5 protein and how these changes affect ERK phosphorylation and proliferation. NPA induction of DUSP5 protein was greatest at 2 hours. Real time PCR revealed the greatest increases between 2 hours and 4 hours. The quality of the time course for the western blot does not give enough information about whether the protein levels remain elevated between 2 hours and 6 hours. This timeframe is important because the pERK changes were seen at 4 hours. In NCI-H69 lines our laboratory reported that pERK was reduced prior at times longer than hour suggesting this effect occurs very quickly.

Further analysis of both proteins should be carried out by stripping and reprobing the same western blot to further correlate the times. DUSP5 may lead to an overall reduction in ERK phosphorylation levels. In addition, DUSP5 might reduce ERK phosphorylation in the nucleus, which might not be detectable by analyzing total pERK levels. It has been reported that DUSP5 anchors ERK in the nucleus and isolates ERK cytosolic kinases and targets (Keyse 2005). Localization is an important factor in how ERK signals. Determining how pERK localization correlates with that of DUSP5 is an important next step in understanding the pathway for D2R mediated proliferation. Also, an assay to determine if D2R signaling generates increases in phophatase activity would help to determine that DUSP activity is leading to reductions in pERK.

While only correlations, these results suggest that $\mathrm{D} 2 \mathrm{R}$ activation results in increases in DUSP5 mRNA and protein, and putatively leads to reduced ERK phosphorylation. Much information about the D2R signaling pathway has been determined in other cell lines. We sought to determine the intermediates leading to the increased DUSP5 expression. In NCI-H69 cells, the D2R mediated antiproliferative effect was reported to be mediated by PLD (Senogles 2007). We wanted to determine if PLD was involved in induction of DUSP5. 


\section{ETHANOL INHIBITION OF NPA MEDIATED INDUCTION OF DUSP5 AND DUSP4, BUT NOT DUSP1}

\section{Exerimental Reasoning}

Treatment of DMS 53 cells with NPA resulted in increases in DUSP1, DUSP4 and DUSP5 mRNA expression were observed through real time PCR. Our overarching hypothesis is shown in Figure 1.2. Activation of the D2R receptor stimulates PLD activity. The PLD generated PA, possibly through the action of PLA2 results in the release of AA. The AA or a metabolite of AA is responsible for the changes in mRNA for the DUSPs. This change in expression of DUSPs results in the dephosphorylation of $\mathrm{pERK}$ and a resultant reduction in proliferation.

We wanted to test if known inhibitors of the antiproliferative effect would also inhibit the increases in the mRNA of the DUSP family of genes. To this end, we selected two inhibitors of the D2R mediated signaling pathway (Figure 1.2). Phospholipase D has been demonstrated to mediate the antiproliferative effect in primary lactotrophs as well as in SCLC cell line, NCI-H69 (Senogles 2007). In order to determine if PLD was also involved in DUSP induction, ethanol was added to inhibit the generation of PA. As mentioned previously, PLD can use a primary alcohol as substrate with the generation of phosphatidylethanol instead of PA. The addition, of ethanol to DMS 53 cells, results in the inhibition of PA dependent downstream signaling.

DMS53 cells were treated with $1 \mu \mathrm{M} \mathrm{NPA}, 1 \mu \mathrm{M}$ NPA plus $0.5 \%$ ethanol or ethanol alone. NPA was added for 6 hours, while ethanol addition was delayed and remained on cells for the final 2 hours.

\section{Result of Ethanol Addition Experiment}

\section{DUSP5}

Ethanol treatment of DMS 53 cells reduced the previously observed NPA induction of DUSP 5 mRNA (Figure 3.10). The 0.28 fold induction $(n=45, p<0.001$ ) of DUSP5 by NPA was reduced $29 \%(n=51, p<0.05)$ to 0.20 fold above vehicle in conjunction with $0.5 \%$ Ethanol addition to NPA. Ethanol alone did not affect significantly affect DUSP5 expression compared to vehicle control $(\mathrm{n}=27, \mathrm{p}=0.65)$.

\section{DUSP4}

NPA induced, DUSP4 (MKP-2) expression was minimal at 0.10 fold above vehicle (Figure 3.11), but statistically significant $(n=23, p<0.05)$. This induction was completely abolished when Ethanol was added in conjunction with NPA $(n=23, p<0.001)$. 


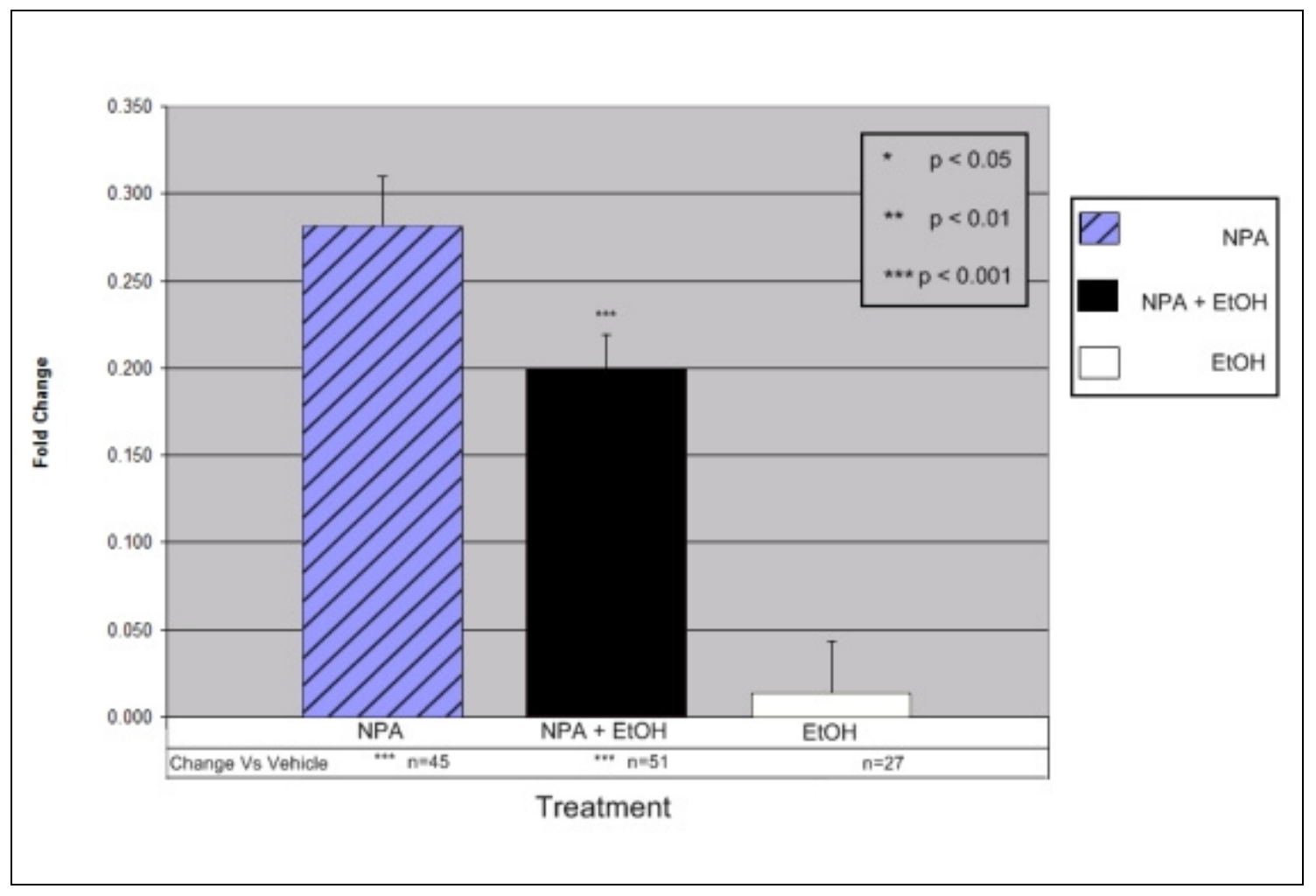

Figure 3.10. Effect of Ethanol on DUSP5 Expression as Revealed by Real Time PCR. DMS 53 cells were treated for 6 hour with $1 \mu \mathrm{M}$ NPA, $1 \mu \mathrm{M} \mathrm{NPA}+0.5 \%$ ethanol for 2 hours or ethanol alone. All samples were standardized using cyclophilin D. The fold change is calculated by taking the NPA treated samples divided by the vehicle. A baseline of zero indicates no change compared to vehicle control. 


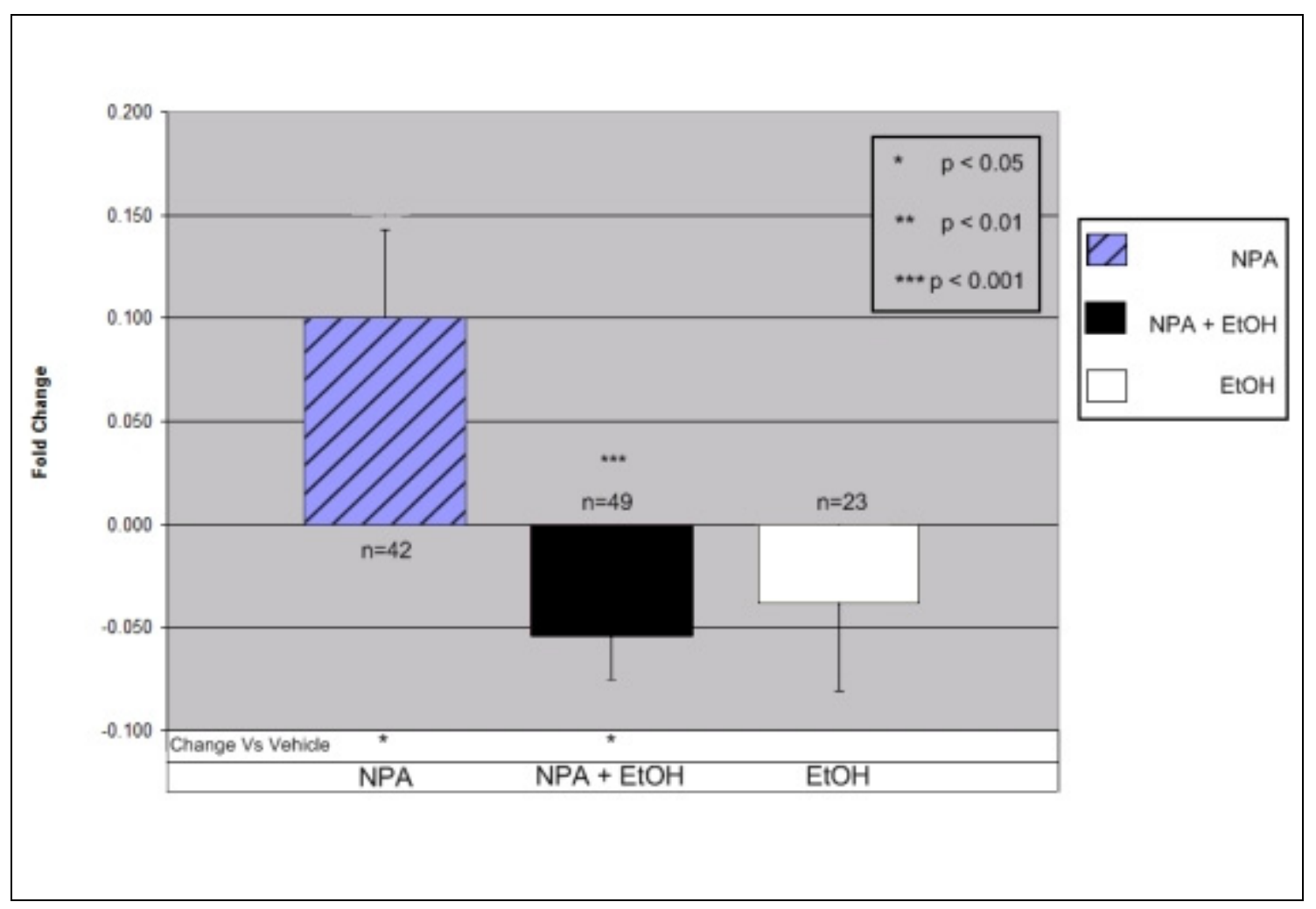

Figure 3.11. Effect of Ethanol on DUSP4 Expression as Revealed by Real Time PCR. DMS 53 cells were treated for 6 hours with $1 \mu \mathrm{M}$ NPA, $1 \mu \mathrm{M}$ NPA $+0.5 \%$ ethanol for 2 hours or ethanol alone All samples were standardized using cyclophilin D. The fold change is calculated by taking the NPA treated samples divided by the vehicle. A baseline of zero indicates no change compared to vehicle control. 


\section{DUSP1}

In contrast, the expression of DUSP1 mRNA (MKP-1) was increased by Ethanol as compared to vehicle control (Figure 3.12). Addition of Ethanol alone resulted in 0.37 fold increases of DUSP1 $(n=25, \mathrm{p}<0.001)$. As a result, the NPA induced DUSP1 expression was actually increased from 0.5 fold above vehicle $(n=32, p<0.001)$ to 0.67 fold $(n=46$, $\mathrm{p}<0.001)$ compared to vehicle. This additional $25 \%$ induction of DUSP 1 by Ethanol and NPA, reached marginal statistical significance of $\mathrm{p}<0.05$.

\section{Other DUSP Family Members}

Addition of Ethanol alone had little effect on the expression of mRNA of other DUSPs tested (data not shown). The expression of DUSP3 mRNA was marginally reduced by ethanol alone $(n=25, p<0.05)$, with a 0.19 decrease compared to vehicle control. In addition Ethanol statistically increased DUSP9 mRNA expression by 0.15 fold. Neither DUSP2 $(n=25, p=0.997)$, DUSP6 $(n=27, p=0.84)$, DUSP7 $(n=26, p=0.84)$ or DUSP14 $(n=7, p=0.97)$ mRNA expression were changed significantly by addition of Ethanol.

\section{Discussion of Ethanol Addition Experiment}

Ethanol inhibited the NPA induction of DUSP4 and DUSP5. Ethanol alone did not significantly effect the expression of either of these genes. The Ethanol and NPA combination did not result in reduced DUSP1 compared to levels seen in NPA treated cells. However, Ethanol alone did increase DUSP1 mRNA relative to vehicle control. For this reason we suspect that Ethanol related cellular stress activates another pathway. DUSP1 has little preference for JNK, p38 and ERK as substrates (Owens and Keyse 2007). As a result, DUSP1 is involved in a large number of processes and has been shown to be rapidly induced by inflammatory stimuli (Wang 2007). As a result it is difficult to test how the inhibition of PA production through ethanol may affect the NPA induction of this gene. In other cell lines, ethanol treatment inhibits the antiproliferative effects of DA (Senogles 2007). This suggests that DUSP1 is not involved in this process, a hypothesis that is supported by the inability of NPA to induce MKP-1 (DUSP-1) through western blot.

This collection of data suggests that DUSP 4 and 5 may be the phosphatases involved in the antiproliferative effect of D2R agonists. The expression of mRNA for both DUSP 4 and 5 was sensitive to the presence of ethanol, which suggested that the mRNA for these proteins may be regulated by PLD. 


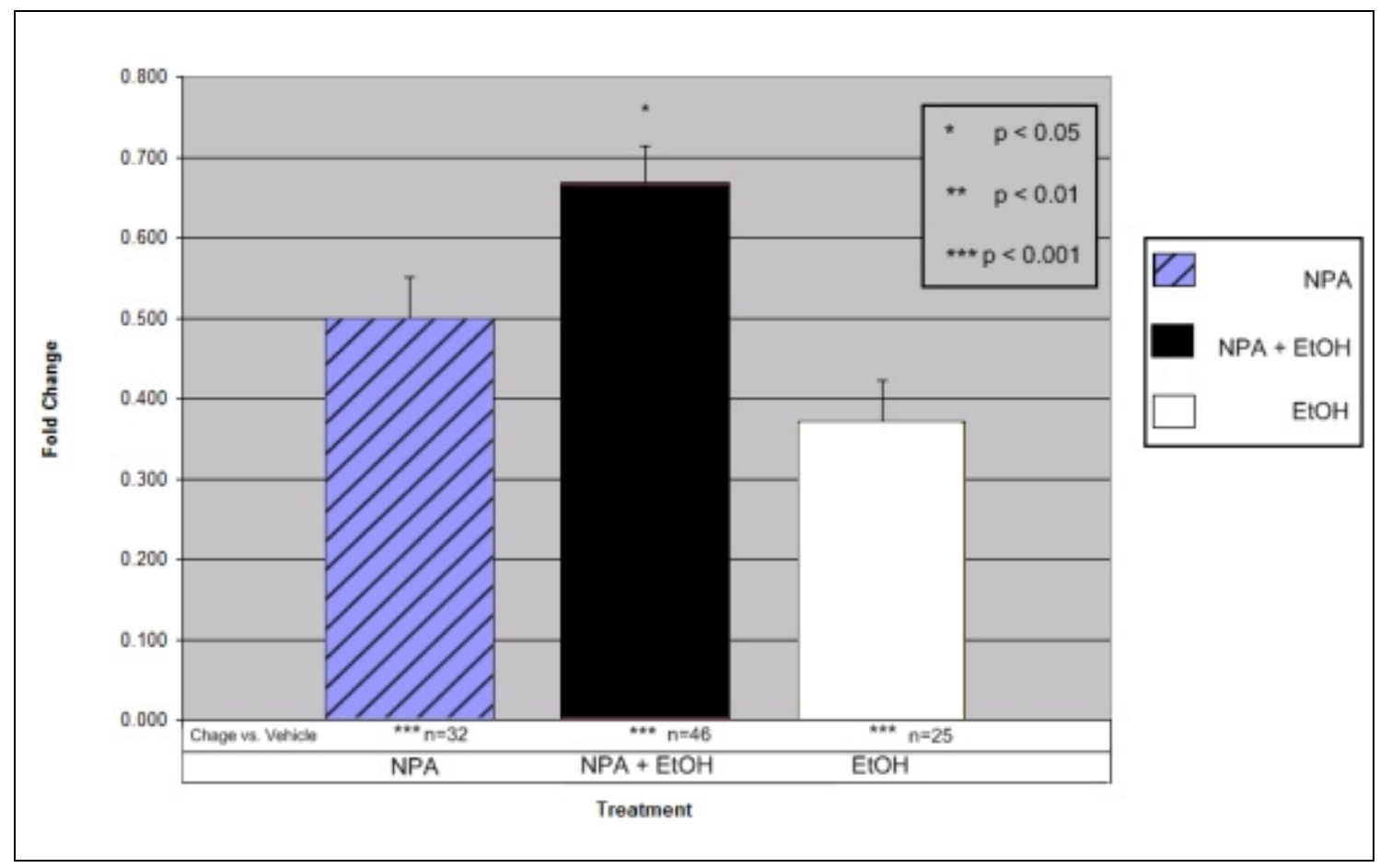

Figure 3.12. Effect of Ethanol on DUSP1 Expression as Revealed by Real Time PCR. All samples were standardized using cyclophilin D. The fold change is calculated by taking the NPA treated samples divided by the vehicle. A baseline of zero indicates no change compared to vehicle control. 


\section{INCREASED DUSP1, DUSP4 AND DUSP5 EXPRESSION FOLLOWING AA TREATMENT}

\section{Experimental Reasoning}

AA involvement in the induction of DUSP1 (MKP-1), as observed by Metzler et al. 1996, occurred in Vascular Smooth muscle cells. D2R potentiated AA release has been demonstrated in CHO (Piomelli 1991), lactotroph and SCLC cell lines (Senogles, unpublished observations). In DMS 53 cells, we have observed D2R potentiated increases in several of the DUSPs. We wanted to determine if direct application of AA would generate similar changes in expression of these genes in DMS 53 cells as those observed with NPA treatment. AA, from Porcine Liver, Sodium Salt (Calbiochem) was stored in $-20 \mathrm{C}$, dissolved in distilled-deionized water before adding to cells. AA was added to cells for 5 hours prior to lysis.

\section{Result of AA Treatment of DMS 53 Cells}

Significant concentration-dependant increases were seen in DUSP1 (MKP-1), DUSP4 (MKP-2) and DUSP5 mRNA's following the addition of AA. Note that these experiments are performed in the absence of NPA as we are evaluating the effects of AA alone.

\section{DUSP1}

Treatment of DMS 53 cells with AA resulted in an increase of expression for the mRNA for DUSP1 (MKP-1) compared to vehicle control levels (Figure 3.13). The increases in DUSP1 mRNA expression demonstrated concentration dependence up to $50 \mu \mathrm{M}$.

Significant increases in mRNA for DUSP1 were observed with addition of $10 \mu \mathrm{M}(0.22$ fold change, $\mathrm{n}=21, \mathrm{p}<0.001), 50 \mu \mathrm{M}(0.68$ fold change, $\mathrm{n}=92, \mathrm{p}<0.001)$ and $200 \mu \mathrm{M}$ ( 0.53 fold change, $n=15, p<0.001)$. At $1 \mu \mathrm{M}$ concentration of $\mathrm{AA}$, a minor inhibition of 0.06 fold in mRNA expression was observed $(n=30, p<0.001)$.

\section{DUSP4}

The addition of AA to DMS 53 cells resulted in significant increase of the mRNA for DUSP4 at $50 \mu \mathrm{M}$ and $200 \mu \mathrm{M}$ (Figure 3.14). The changes in DUSP4 were the strongest with $50 \mu \mathrm{M}$ addition $(0.33$ fold increase, $\mathrm{n}=73, \mathrm{p}<0.001)$ even more than those seen at $200 \mu \mathrm{M}(0.10$ fold increase, $\mathrm{n}=21, \mathrm{p}<0.001)$.

\section{DUSP5}

DUSP5 showed a dose dependence on AA concentration. The changes in mRNA observed gradually increased, with 0.16 fold increases seen at $10 \mu \mathrm{M}$ AA addition. The changes were larger $(0.33$ fold, $n=74, \mathrm{p}<0.001)$ at $50 \mu \mathrm{M}$ and reached the 


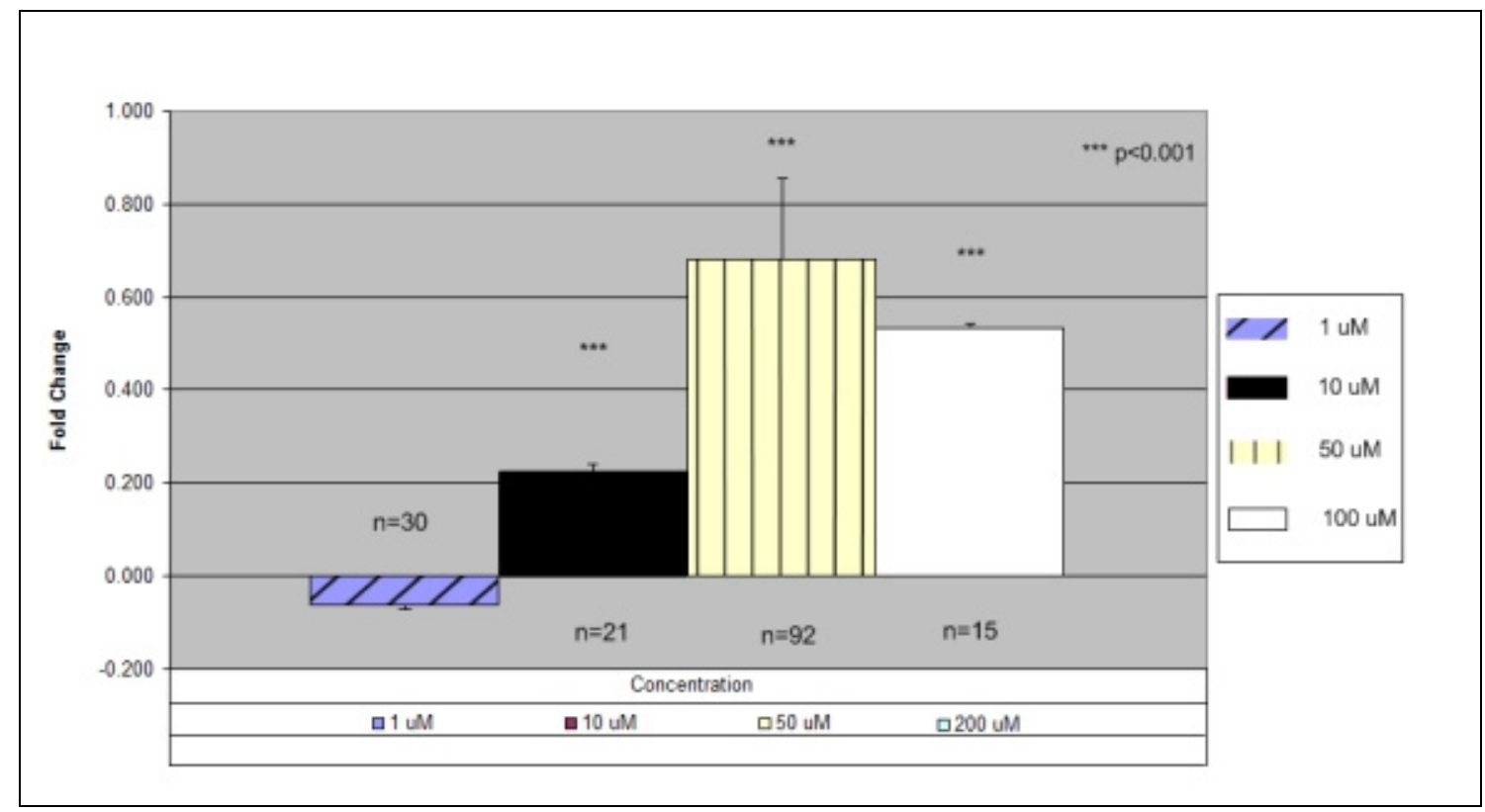

Figure 3.13. Effect of AA on DUSP1 Expression as Revealed by Real Time PCR Analysis. All samples were standardized using cyclophilin D. The fold change is calculated by taking the NPA treated samples divided by the vehicle. A baseline of zero indicates no change compared to vehicle control. 


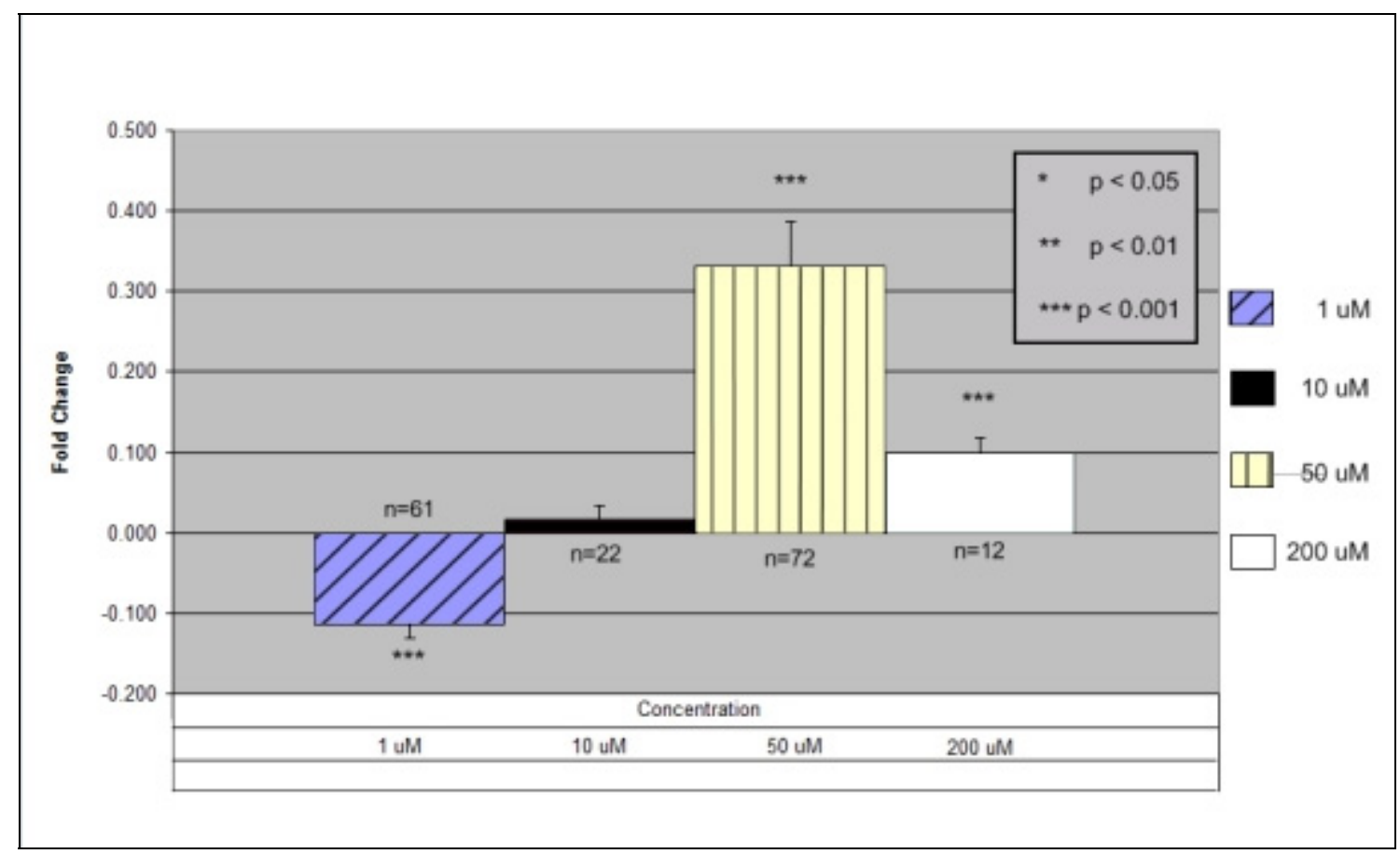

Figure 3.14. Effect of AA on DUSP4 Expression as Revealed by Real Time PCR Analysis. All samples were standardized using cyclophilin D. The fold change is calculated by taking the NPA treated samples divided by the vehicle. A baseline of zero indicates no change compared to vehicle control. 
maximum of 0.58 fold $(n=15)$ at $200 \mu \mathrm{M}$ (Figure 3.15).

Of the remaining DUSP genes, minimal changes in expression of mRNA were seen (Figure 3.16) and those changes were only seen at $200 \mu \mathrm{M}$ for DUSP 3 (0.08 fold, $\mathrm{p}<0.01, \mathrm{n}=15)$ at $50 \mu \mathrm{M}$ for DUSP $9(0.10, \mathrm{n}=58, \mathrm{p}<0.05)$ and DUSP 14 (0.08 fold, $\mathrm{n}=51$, $\mathrm{p}<0.05)$. No changes in expression of mRNA for DUSP7 expression were evident.

\section{Discussion of AA Treatment of DMS 53 Cells}

The addition of AA to DMS 53 cells resulted in significant changes in DUSP1 in as little as $10 \mu \mathrm{M}$ and increased until $50 \mu \mathrm{M}$. Induction of DUSP1 at $200 \mu \mathrm{M}$ fell slightly compared to those at $50 \mu \mathrm{M}$. This may indicate that some other factor is being changed at high concentrations. More likely however is that the difference between these two is an experimental difference. At $200 \mu \mathrm{M}$ the number of trials was reduced, increasing the likelihood that greater variation may be seen. Increases in AA induced DUSP5 increased with concentration, reaching a maximum at $200 \mu \mathrm{M}$. These levels were markedly above the levels of increased mRNA expression seen by random experimental variation. The results here suggest that AA does induce DUSP5. DUSP4 reached a maximum at $50 \mu \mathrm{M}$. At this concentration, the levels were above 0.30 fold change, approximately double those seen in genes with no change. At this concentration enough trials were performed to reduce unwanted statistical variation. Taken together these data suggest that AA induces mRNA expression of DUSP1, DUSP4 and DUSP5.

Addition AA resulted in ablation of NPA induced DUSP mRNA. We were unsure exactly how PA may be leading to increased DUSP expression. Our overall hypothesis was that AA was being produced downstream of PA. The changes in expression induced by AA were similar in magnitude to the changes observed in response to NPA. In both experiments we witnessed the greatest changes in DUSP1 and DUSP5 with minor increases in DUSP4. This correlation suggests that AA may in fact be produced in response to NPA and this production may lead to the induction of DUSP1, DUSP4 and DUSP5. However, we have yet to establish that AA production as a result of DA signaling actually led to the induction of the mRNA of these three genes. We sought to inhibit the actions of AA following NPA addition and then evaluated the induction of these genes.

\section{REDUCTION OF DUSP1, DUSP4 AND DUSP5 INDUCTION BY NPA FOLLOWING ADDITION OF AA INHIBITORS}

\section{Experimental Reasoning}

As shown in the previous section, AA alone would bring about changes in the mRNA expression for a number of DUSPs. Our hypothesis is that if NPA induced expression of DUSPs is AA dependent, an inhibitor of AA should block the changes in mRNA 


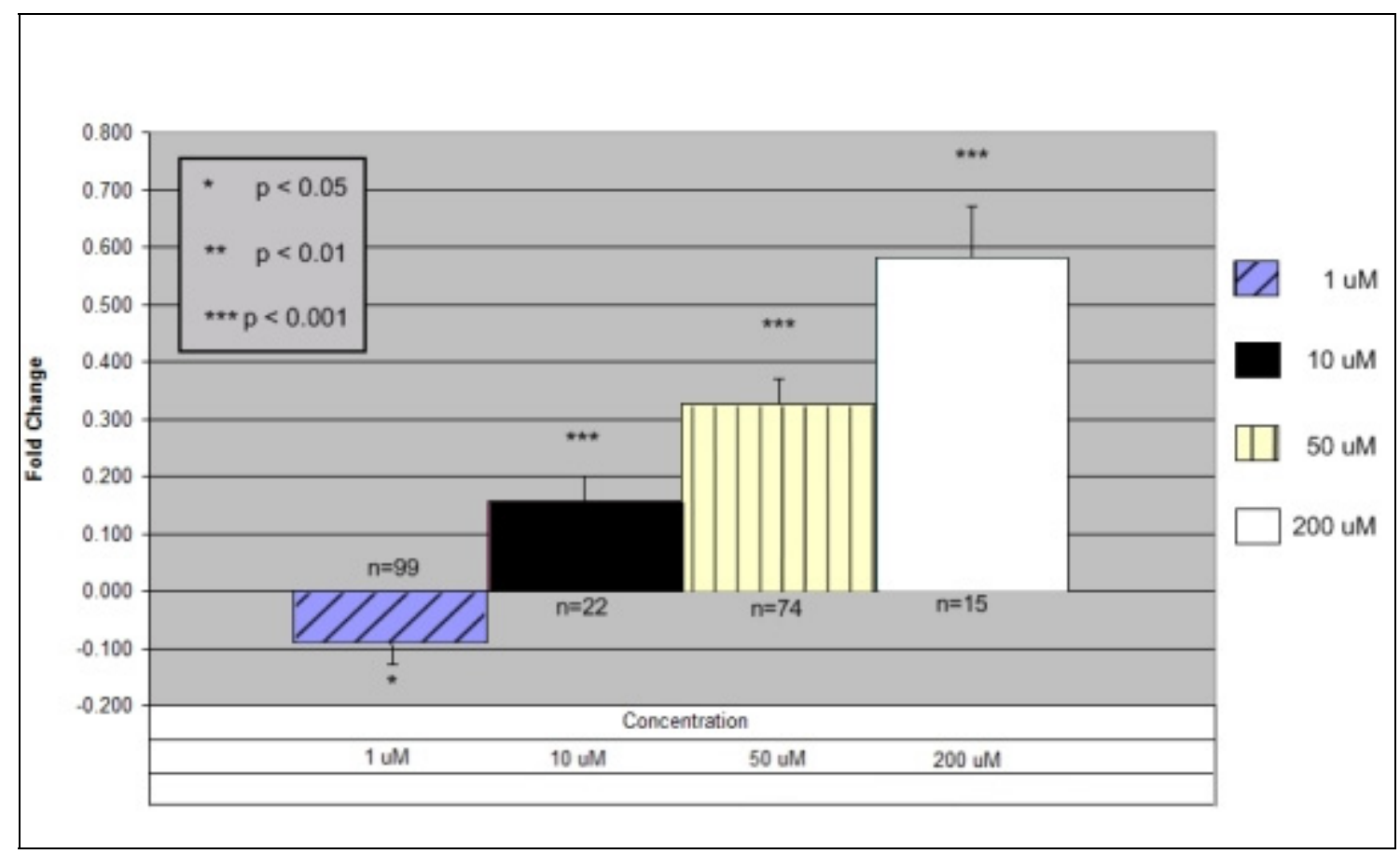

Figure 3.15. Effect of AA on DUSP5 Expression as Revealed by Real Time PCR Analysis. All samples were standardized using cyclophilin D. The fold change is calculated by taking the NPA treated samples divided by the vehicle. A baseline of zero indicates no change compared to vehicle control. 


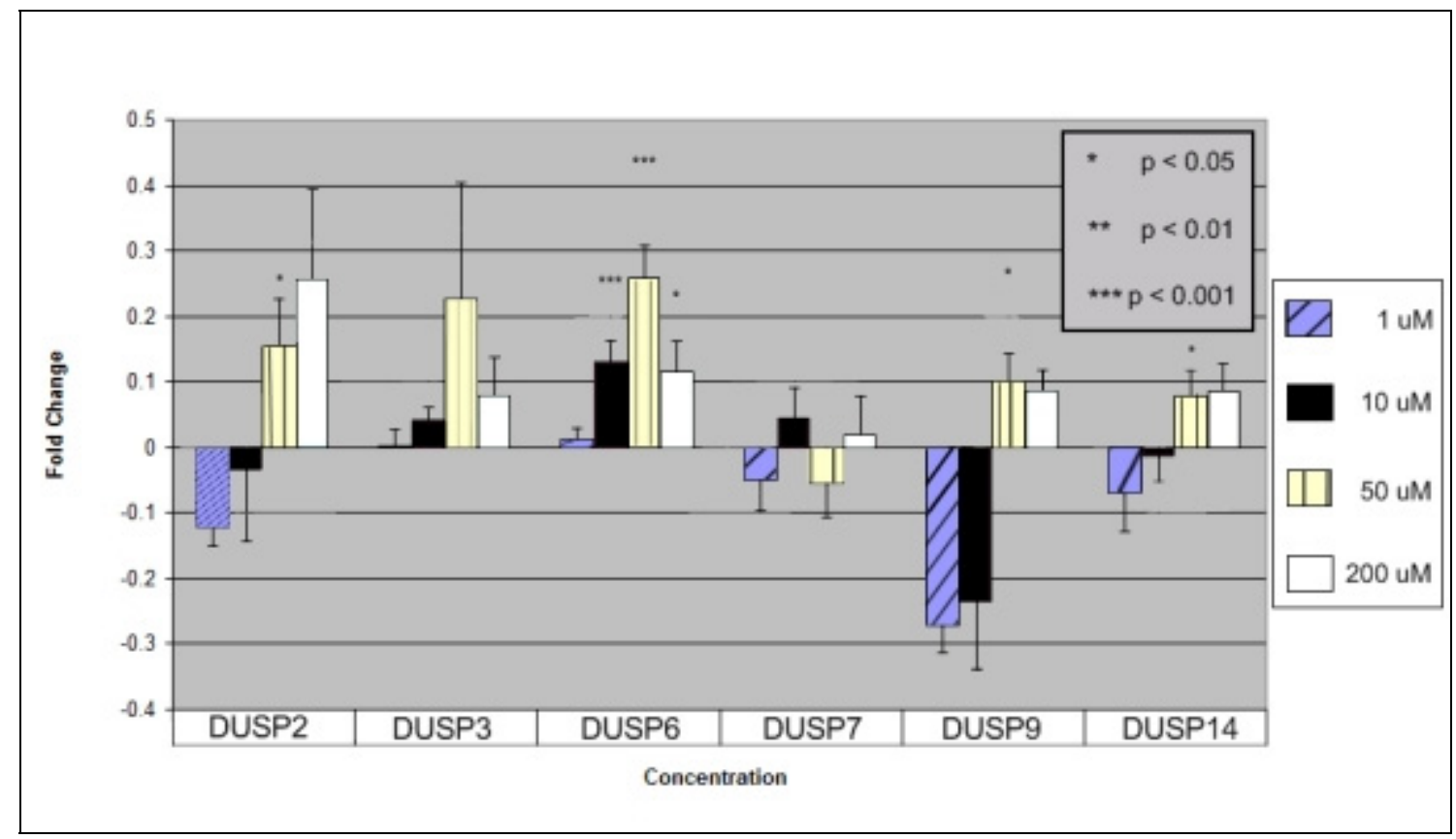

Figure 3.16. Effect of AA on DUSP Expression as Revealed by Real Time PCR Analysis. All samples were standardized using cyclophilin D. The fold change is calculated by taking the NPA treated samples divided by the vehicle. A baseline of zero indicates no change compared to vehicle control.

observed with AA. For this reason, we chose to investigate the effects of ETYA on expression of DUSPs by real time PCR.

5,8,11,14-eicosatetraynoic acid (ETYA) is a cell permeable and nonhydrolyzable analog of AA (5,8,11,14-eicosatetraenoic acid), which competitively inhibits AA (Ondrey 1989; Taylor 1985). ETYA has been shown to inhibit phospholipase A2 (PLA2) and cytochrome P-450. In addition, it has also been shown to inhibit cyclooxygenase, 5lipoxygenase, 12-lipoxygenase and 15-lipoxygenase (Ekokoski 1994; Honda 1999; Ondrey 1989).

NPA was added to all conditions at a concentration of $1 \mu \mathrm{M}$. ETYA was dissolved in DMSO and added to culture media at a final concentration of $10 \mu \mathrm{M}$ ETYA and $0.01 \%$ DMSO. The conditions for treatment were NPA or NPA with ETYA/DMSO or DMSO alone. Each well of a six well cluster dish corresponded to one condition: NPA alone, NPA plus ETYA/DMSO or NPA plus DMSO alone and cells were allowed to incubate in normal culture conditions for 4 hours. At the end of the test period, media was aspirated, cells were washed and RNA extracted as described in methods. 


\section{Result of ETYA Addition to DMS 53 Cells}

\section{DUSP1}

As confirmation of previous results, NPA increased DUSP1 expression 0.72 fold above vehicle control $(n=42, p<0.001)$ as shown in Figure 3.17. The addition of $10 \mu$ M ETYA in $0.01 \%$ DMSO reduced the mRNA for DUSP1 by $46 \%$ compared to NPA alone, and 0.39 fold compared to the DMSO vehicle $(n=60, p<0.001)$. The changes in DUSP expression were not a result of DMSO present in the media as DMSO alone did not significantly change NPA induced DUSP 1 expression resulting in 0.65 fold increase over vehicle $(n=30, p=0.38)$.

\section{DUSP5}

Addition of NPA alone resulted in a 0.45 fold increase in DUSP5 mRNA expression over vehicle control. This increase in expression by NPA was ablated by $56.5 \%$ with the inclusion of ETYA compared to vehicle $(n=48, p<0.001)$. The addition of DMSO (0.341 fold, $n=36, p=0.16)$ did not significantly inhibit DUSP5 mRNA induction by NPA (Figure 3.18).

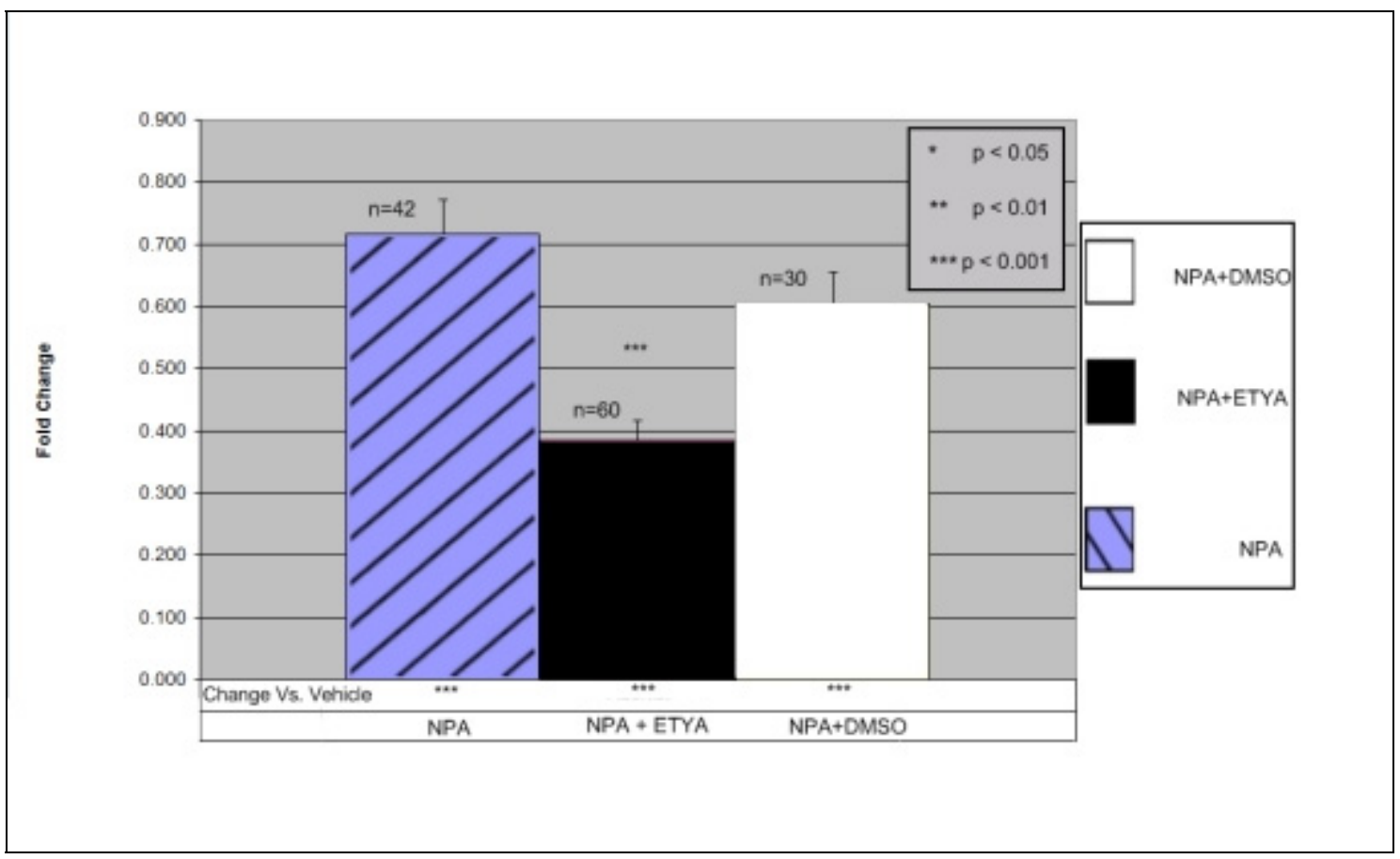

Figure 3.17. Effect of $10 \mu M$ ETYA Added to $1 \mu M$ NPA Treatment on DUSP1 as Revealed by Real Time PCR. Fold change is calculated relative to vehicle control. Significance levels in the upper portion of the graph represent the comparison of NPA alone to the other treatment conditions. 


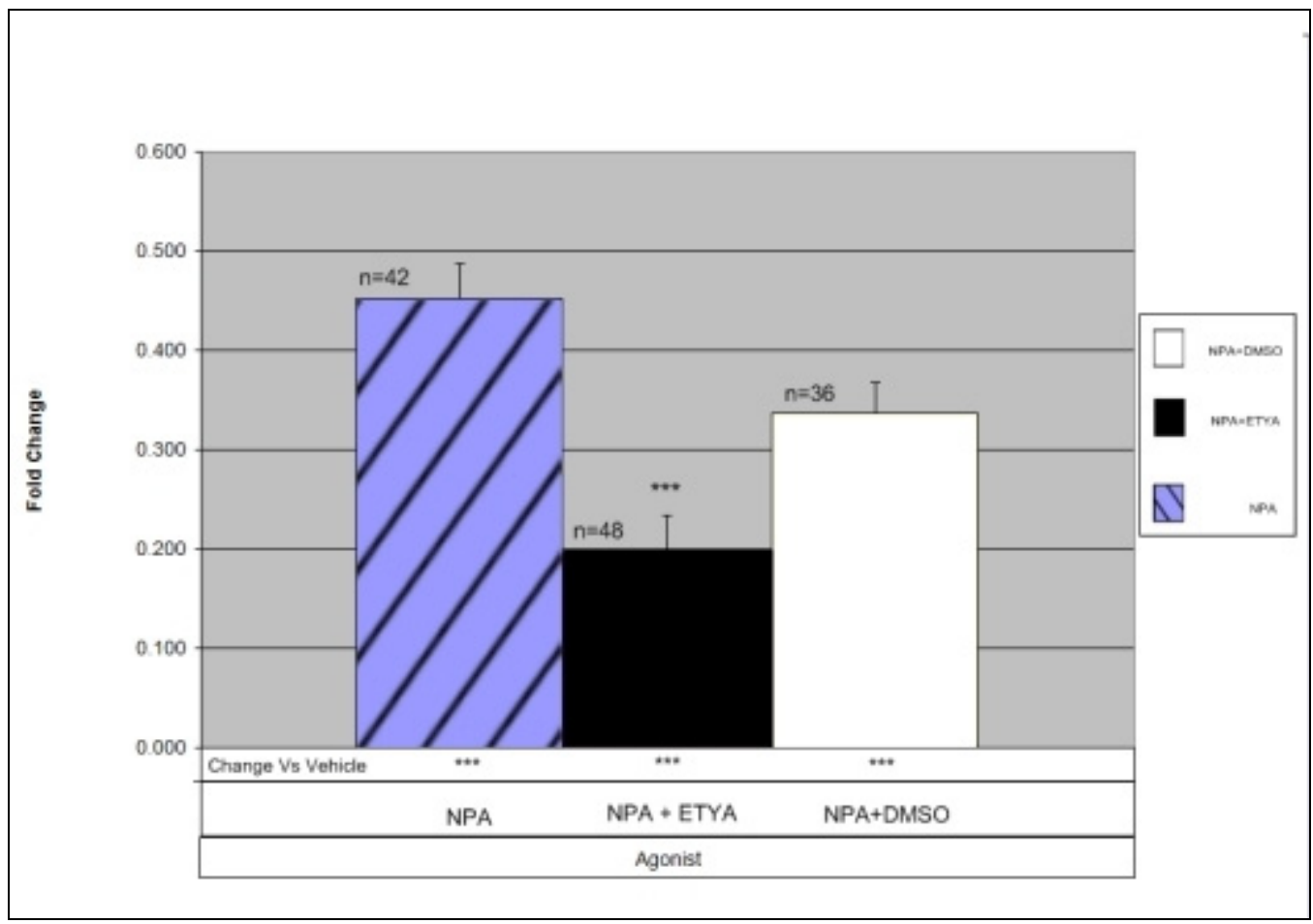

Figure 3.18. Effect of $10 \mu M$ ETYA Added to $1 \mu M$ NPA Treatment on DUSP5 as Revealed by Real Time PCR. Fold change is calculated relative to vehicle control. Significance levels in the upper portion of the graph represent the comparison of NPA alone to the other treatment conditions. 


\section{DUSP4}

While the addition of NPA increased the expression of mRNA for DUSP4 (MKP-2) 0.23 fold compared to control $(n=36, p<0.001)$, these changes were similar to those seen overall (Figure 3.19). The induction of DUSP 4 mRNA by NPA was completely abolished by ETYA $(n=54, p<0.001)$ and registered a reduction of mRNA expression by 0.21 fold compared to vehicle $(\mathrm{p}<0.001)$.

\section{Discussion of ETYA Addition to DMS 53 Cells}

The addition of ETYA resulted in complete inhibition of NPA mediated increases in DUSP4 and partial inhibition of increases in DUSP1 and DUSP5. DMSO as a vehicle did not have any effect on the NPA induction of these genes. These results indicate that AA is involved in the NPA induction of these genes. Following the induction of these DUSPs with external application of AA, we expected DUSP4 and DUSP5 to be inhibited by ETYA. The induction of both of these genes appeared to be dependent on PA as indicated by the inhibition with ethanol. Our expectation was that PA produced would be metabolized to AA. 


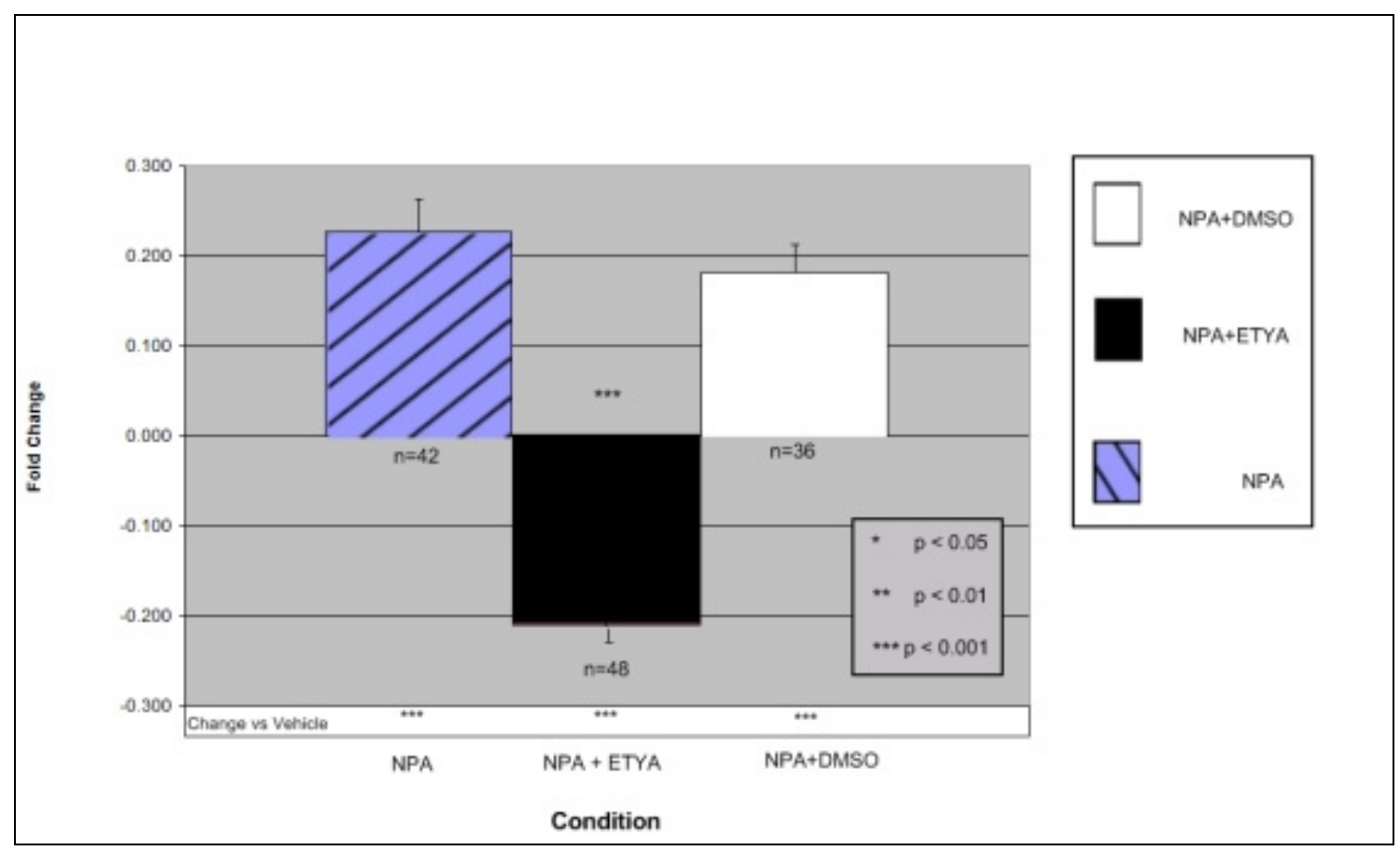

Figure 3.19. Effect of $10 \mu M$ ETYA Added to $1 \mu M$ NPA Treatment on DUSP4 Expression as Revealed by Real Time PCR. Fold change is calculated relative to vehicle control. Significance levels in the upper portion of the graph represent the comparison of NPA alone to the other treatment conditions. 


\section{CHAPTER 4. SUMMARY/CONCLUSION}

Our overarching hypothesis was that the D2R dopamine receptor mediated signaling impacted the expression of DUSP family of proteins. We hypothesized that the D2R receptor, through stimulation of PLD and generation of PA, would impact DUSP expression. The proposed pathway suggests that PA may be metabolized through the action of cPLA2 to generate AA. AA generated in this method might directly or indirectly lead to increased DUSP mRNA, followed by greater protein levels and phosphatase activity generated toward ERK.

Our first step to evaluate this hypothesis was to confirm D2R mediated antiproliferation in DMS53 cells. We observed modest reductions in proliferation through the cyquant NF proliferation assay, which is based on DNA content of cells. We concluded that in this SCLC cell line that NPA would result in a reduction in proliferation. This effect has been observed by our laboratory in other SCLC cell lines as well as GH4C1 and HEK cells transfected with the cDNA of the D2R. Next we sought to determine if expression of any DUSP genes were increasing following D2R stimulation. We chose to use RT-PCR for this set of experiments. The primary reason for this choice was that we could we could evaluate a number of DUSP genes simultaneously. Primers for DUSP1, 2, 4, 5, 6, 7 and 14 were validated and expression levels were determined through real time PCR analysis. We evaluated gene expression for each of these genes in the presence and absence of NPA and found a number of changes. Addition of NPA resulted in significant increases in the expression of DUSP1 (MKP-1), DUSP4 (MKP-2) and DUSP5 mRNA. We observed increases in all three genes at the two and six hour time points. Insignificant levels of the remaining DUSPs demonstrated the experimental variation involved in the real time PCR and indicated the sensitivity of the assay. Changes following addition of NPA of the mRNA for DUSP4 and DUSP14 were in the range that we believed to be due to experimental variability as determined by evaluating how genes with no statiscal significance varied positively and negatively inside this range. As changes in expression for these genes were inside this range, we had reason to expect type one statistical errors even though statistical significance was reached. NPA consistently induced changes in DUSP4 in each experiment where NPA induction was used as a positive control. In addition, we had previously seen NPA induced changes in MKP-2 (DUSP4) in other SCLC cell lines, leading us to believe that the modest NPA induced changes in DUSP4 mRNA may contribute to changes in protein levels. While the DUSP4 levels were modest, DUSP1 and DUSP5 were induced at the highest levels of significance and approximately three times the experimental variation.

Next, we wanted to determine the signaling pathway leading to increased DUSP1, DUSP4 and DUSP5 expression. We tested whether NPA induced expression of these genes could be inhibited by inhibiting PA production, using ethanol. Ethanol inhibited NPA induction of DUSP4 and DUSP5, but not DUSP1. Ethanol reduced NPA mediated increase in DUSP5 nearly thirty percent and completely abolished the NPA mediated increase in DUSP4. As a surprise, when added to NPA treated cells, 0.5\% Ethanol, 
actually increased DUSP1 expression. The induction of DUSP1 by ethanol was also observed in the absence of NPA.

We wanted to determine how PA generated through PLD might lead to induction of these genes. We hypothesized that DUSP induction might occur through the metabolism of PA and eventual production of AA. Real time PCR revealed dose dependent, AA induced increases in mRNA for DUSP1, DUSP4 and DUSP5 which mimicked the changes induced by NPA. At similar levels, DUSP1, DUSP4 and DUSP5 were increased by treatment with AA. These results confirmed that mRNA for these genes was increased through external application of AA. Inhibitors of the action of AA, such as ETYA were used to determine if they could block the effects of NPA. The NPA mediated increases in all three of these genes were inhibited by treatment with ETYA. NPA induced significant increases in DUSP1, DUSP4 and DUSP5. ETYA reduced or eliminated the increases due to NPA addition of all three of these DUSP genes. DMSO as a vehicle did not significantly decrease any of the three genes.

Taken together, this information suggests the following conclusion. Expression of DUSP1, DUSP5 and DUSP4 expression levels are mediated by the D2R, activated by NPA. The role of PLD has been shown as ethanol will ablate the changes in mRNA observed with NPA treatment. In addition, treatment of DMS 53 cells with exogenous AA mimics the effects observed with D2R agonist. These data are consistent with a model in which D2R agonists stimulate PLD, resulting in the release of PA which is metabolized to AA. In turn, AA either directly or through a metabolite, brings about the increases in DUSP mRNA.

DUSP5 is the strongest candidate as the phosphatase responsible for the dephosphorylation of ERK in the D2R mediated antiproliferative effect. Western Blot for DUSP5 show subsequent changes in protein levels following NPA stimulation. Of the nuclear inducible DUSPs, DUSP5 is also the most specific toward ERK (Owens and Keyse 2007). Increased DUSP5 has been shown to bind ERK, inactivate it through dephosphorylation and anchor it in the nucleus, thus preventing ERK from being phosphorylated again (Keyse 2005). However, it should not be ruled out that these DUSP genes are working in concert to reduce ERK phosphorylation as each of these genes code for proteins which exhibit some phosphatase activity toward ERK (Owens and Keyse 2007).

We hypothesize that these changes occur through the following pathway (Figure 4.1). Treatment of DMS 53 cells with NPA results in the stimulation of PLD and the production of PA. Ethanol inhibition of NPA stimulated expression of DUSP5 and DUSP4 suggests the induction of these genes is dependant on PA released from PLD activity. Metabolism of PA through unverified mechanisms generates AA. AA generated from PA induces RNA expression of DUSP1 (MKP-1), DUSP4 and DUSP5 through unknown molecular mechanisms. The increased DUSP5 mRNA results in increased protein which binds and dephosphorylates ERK. 


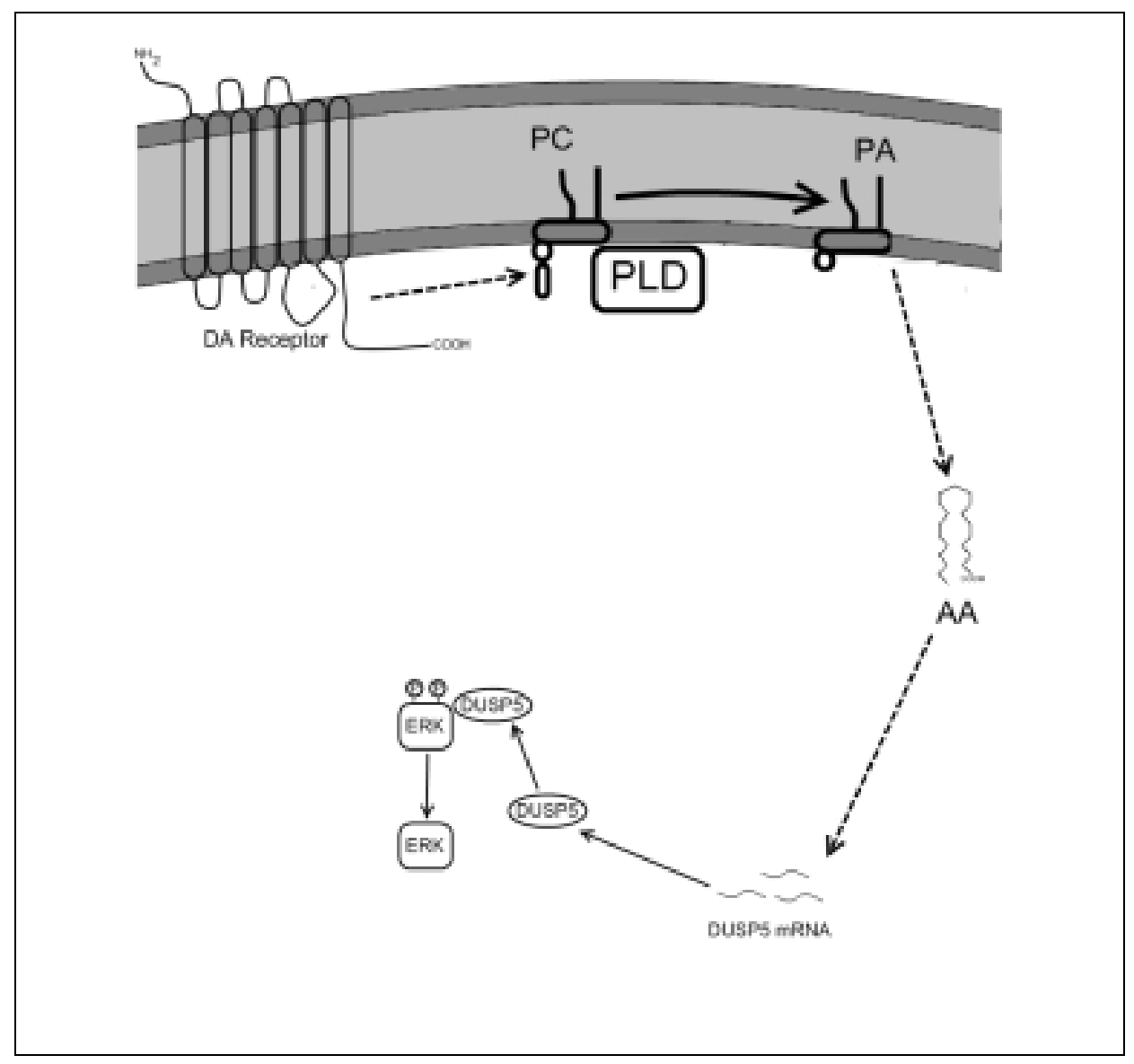

Figure 4.1. Proposed Mechanism for D2R Mediated Antiproliferation. D2R binding indirectly activates PLD, which catalyzes the conversion of PC to PA. PA is metabolized through unverified pathways leading to AA release. AA leads to increased DUSP5 mRNA and protein. DUSP5 binds phosphorylated ERK and dephosphorylates ERK. 
The information generated from these experiments answers some questions while others are unanswered. AA dependent DA induction of DUSP4 and DUSP5 correlates with changes in proliferation. Logically, DUSP induction would lead to reduction of pERK and subsequently reduce proliferation. Several experiments remain to ensure that all of the events in this thesis are directly connected. However, this information lends support to the hypothesis that PLD is activated leading to AA release and subsequent changes in DUSP5 and DUSP4 through unknown mechanisms.

Further investigation is required to determine whether DUSP expression directly influences changes in ERK phosphorylation and activity and subsequent changes in proliferation. We observed D2R mediated changes in ERK phosphorylation and also increased DUSP5 immunoreactivity. It has been reported that DUSP5 can anchor in the nucleus and reduce phosphorylation of ERK (Keyse 2005). Ultimately, we would like to evaluate the cellular consequences of inhibiting DUSP5 specifically. However, DUSP5 specific inhibitors are not yet designed. Employing other technologies such as siRNA to knockout DUSP5 and determining the effect on NPA reduction in proliferation and ERK phosphorylation would allow us to determine if DUSP5 is sufficient to inhibit these effects. This knockout also would answer questions or whether DUSP5 resides upstream of ERK in the antiproliferative pathway.

Another question still left unanswered is the mechanism through which AA is generated in this pathway. In our hypothesis there are two possible methods whereby PA might be metabolized to AA (Figure 1.2). AA release is primarily a result of cytosolic Phospholipase A2 (Lin 1992). If D2R receptor mediated DUSP expression is PLA2 dependent, this expression should be inhibited by PLA2 inhibitors.

In addition, questions remain about the discrepancies between the DUSP1 and the DUSP4/DUSP5 induction by NPA. Ethanol may be inducing DUSP1 through a separate mechanism. DUSP1 is largely involved in JNK expression. Ethanol may induce cellular stress which is sufficient to induce JNK and DUSP1 expression is induced by JNK as a feedback mechanism. DUSP1 induced through this pathway. Alternatively, PLD activity may lead to localized concentrations of AA which generate changes in DUSP4 and DUSP5, but do not effect on DUSP1 induction. 


\section{LIST OF REFERENCES}

1. Albert PR, Neve KA, Bunzow JR, Civelli O. (1990). Coupling of a cloned rat dopamine-D2 receptor to inhibition of adenylyl cyclase and prolactin secretion. J Biol Chem. Feb 5;265(4):2098-104.

2. Banihashemi B, Albert PR. (2002). Dopamine-D2RS receptor inhibition of calcium influx, adenylyl cyclase, and mitogen-activated protein kinase in pituitary cells: distinct $\mathrm{G}$ alpha and $\mathrm{G}$ betagamma requirements. Mol Endocrinol. Oct;16(10):2393404.

3. Bjorklund A, Dunnett SB. (2007). Fifty years of dopamine research. Trends Neurosci. May;30(5):185-7.

4. Bradford MM. (1976). A rapid and sensitive method for the quantitation of microgram quantities of protein utilizing the principle of protein-dye binding. Anal Biochem. May 7;72:248-54.

5. Brownson RC, Chang JC, Davis JR. (1992). Gender and histologic type variations in smoking-related risk of lung cancer. Epidemiology. Jan;3(1):61-4.

6. Bustin SA. (2004). A-Z of quantitative PCR. Intern Univer Line. 18:624-40.

7. Canonico PL. (1989). D-2 dopamine receptor activation reduces free $[3 \mathrm{H}]$ arachidonate release induced by hypophysiotropic peptides in anterior pituitary cells. Endocrinology. Sep;125(3):1180-6.

8. Caunt CJ, Finch AR, Sedgley KR, McArdle CA. (2006). Seven-transmembrane receptor signalling and ERK compartmentalization. Trends Endocrinol Metab. Sep;17(7):276-83.

9. Cave JW, Baker H. (2009). Dopamine systems in the forebrain. Adv Exp Med Biol. 651:15-35.

10. Chia MM, Gazdar AF, Carone DP, Minna JP. (1994). Textbook of respiratory medicine. J Biol Chem. 2(270):1458-503.

11. Colao A, Di Sarno A, Pivonello R, di Somma C, Lombardi G. (2002). Dopamine receptor agonists for treating prolactinomas. Expert Opin Investig Drugs. Jun;11(6):787-800.

12. Cooper S, Sprio S. (2006). Small cell lung cancer: treatment review. Respirology. May;11(3):241-8.

13. Cronin MJ, Faure N, Martial JA, Weiner RI. (1980). Absence of high affinity dopamine receptor in $\mathrm{GH} 3$ cells: a prolactin-secreting clone resistant to the inhibitory action of dopamine. Endocrinology. Mar;106(3):718-23.

14. Dal Toso R, Sommer B, Ewert M, Herb A, Pritchett DB, Bach A, Shivers BD, Seeburg PH. (1989). The dopamine D2 receptor: two molecular forms generated by alternative splicing. EMBO J. Dec 20;8(13):4025-34.

15. De Camilli P, Macconi D, Spada A. (1979). Dopamine inhibits adenylate cyclase in human prolactin-secreting pituitary adenomas. Nature. Mar 15;278(5701):252-4.

16. Einhorn LC, Gregerson KA, Oxford GS. (1991). D2 dopamine receptor activation of potassium channels in identified rat lactotrophs: whole-cell and single-channel recording. J Neurosci. Dec;11(12):3727-37. 
17. Ekokoski E, Tornquist K. (1994). Effects of 5,8,11,14-eicosatetraynoic acid on thapsigargin-induced calcium entry, and intracellular $\mathrm{pH}$ in thyroid FRTL-5 cells. Biochim Biophys Acta. Sep 8;1223(2):274-8.

18. Exton JH. (2002). Phospholipase D-structure, regulation and function. Rev Physiol Biochem Pharmacol. 144:1-94.

19. Field JK, Duffy SW. (2008). Lung cancer screening: the way forward. Br J Cancer. Aug 19;99(4):557-62.

20. Fields TA, Casey PJ. (1997). Signalling functions and biochemical properties of pertussis toxin-resistant G-proteins. Biochem J. Feb 1;321:561-71.

21. Florio T, Pan MG, Newman B, Hershberger RE, Civelli O, Stork PJS. (1992). Dopaminergic inhibition of DNA sythesis in pituitary pumor cells is associated with phosphotyrosine phosphatase activity. J Biol Chem. Dec 5;267(34):24169-72.

22. Fukuda M, Adachi M, Nishida E. (2000). Nuclear export of MAP kinase (ERK) involves a MAP kinase kinase (MEK)-dependent active transport mechanism. J Cell Biol. Mar 6;148(5):849-56.

23. Hammond SM, Altshuller YM, Sung TC, Rudg SA, Rose K, Engebrecht J, Morris AJ, Frohman MA. (1995). Human ADP-ribosylation factor-activated phosphatidylcholine-specific phospholipase $\mathrm{D}$ defines a new and highly conserved gene family. J Biol Chem. Dec 15;270(50):29640-3.

24. Hammond SM, Colley WC, Sung TC, Roll R, Jenco J, Altshuller Y, Bar-Sangi D, Morris AJ, Frohman MA. (1997). Phospholipase D2R, a distinct phospholipase D isoform with novel regulatory properties that provokes cytoskeletal reorganization. Curr Biol. Mar 1;7(3):191-201.

25. Honda HM, Leitinger N, Frankel M, Goldhaber JI, Natarajan R, Nadler JL, Weiss JN, Berliner JA. (1999). Induction of monocyte binding to endothelial cells by MM-LDL: role of lipoxygenase metabolites. Arterioscler Thromb Vasc Biol. Mar;19(3):680-6.

26. Hornykiewicz O. (2008). Basic research on dopamine in Parkinson's disease and the discovery of the nigrostriatal dopamine pathway: the view of an eyewitness. Neurodegener Dis. 5(3-4):114-7.

27. Irvine RF. (1982). How is the level of free arachidonic acid controlled in mammalian cells? Biochem J. Apr 15;204(1):3-16.

28. Ishibashi M, Fujisawa M, Furue H, Maeda Y, Fukayama M, Yamaji T. (1994). Inhibition of growth of human small cell lung cancer by bromocriptine. Cancer Res. Jul 1;54(13):3442-6.

29. Jones LJ, Gray M, Yue ST, Haugland RP, Singer VL. (2001). Sensitive determination of cell number using the CyQUANT cell proliferation assay. J Immunol Methods. Aug 1;254(1-2):85-98.

30. Kanaho Y, Yokozeki T, Kuribara H. (1996). Regulation of phospholipase D by low molecular weight GTP-binding proteins. J Lipid Mediat Cell Signal. Sep;14(1-3):2237.

31. Kanterman RY, Mahan LC, Briley EM, Monsma FJ, Sibley DR, Axelrod J, Felder CC. (1991). Transfected D2R dopamine receptors mediate the potentiation of AA release in Chinese hamster ovary cells. Mol Pharmacol. Mar;39(3):364-9.

32. Keyse SM, Karlsson M, Mandl M. (2006). Spatio-temporal regulation of mitogenactivated protein kinase (MAPK) signalling by protein phosphatases. Biochem Soc Trans. Nov;34(Pt 5):842-5. 
33. Keyse SM, Mandl M, Slack DN. (2005). Specific inactivation and nuclear anchoring of extracellular signal-regulated kinase 2 by the inducible dual-specificity protein phosphatase DUSP5. Mol Cell Biol. Mar;25(5):1830-45.

34. Kieling C, Genro JP, Hutz MH, Rohde LA. (2010). A current update on ADHD pharmacogenomics. Pharmacogenomics. Mar;11(3):407-19.

35. Kuroki T, Nagao N, Nakahara T. (2008). Neuropharmacology of second-generation antipsychotic drugs: a validity of the serotonin-dopamine hypothesis. Prog Brain Res. 172:199-212.

36. Laemmli UK. (1970). Cleavage of structural proteins during the assembly of the head of bacteriophage T4. Nature. Aug 15;227(5259):680-5.

37. Lally BE, Urbanic JJ, Blackstock AW, Miller AA, Perry MC. (2007). Small cell lung cancer: have we made any progress over the last 25 years? Oncologist. Sep;12(9):1096-104.

38. Lin LL, Lin AY, Knopf JL. (1992). Cytosolic phospholipase A2 is coupled to hormonally regulated release of arachidonic acid. Proc Natl Acad Sci U S A. Jul 1;89(13):6147-51.

39. Lledo PM, Homburger V, Bockaert J, Vincent JD. (1992). Differential G proteinmediated coupling of $\mathrm{D} 2$ dopamine receptors to $\mathrm{K}+$ and $\mathrm{Ca} 2+$ currents in rat anterior pituitary cells. Neuron. Mar;8(3):455-63.

40. London SM. (2002). The nigrostriatal and mesolimbic dopamine tracts. In: Basic concepts in neuroscience. International edition. New York, NY: McGraw-Hill Medical Publishing Division. 187-208.

41. Mahan LC, Burch RM, Monsma FJ Jr, Sibley DR. (1990). Expression of striatal D1 dopamine receptors coupled to inositol phosphate production and $\mathrm{Ca} 2+$ mobilization in Xenopus oocytes. Proc Natl Acad Sci USA. Mar;87(6):2196-200.

42. Malarkey WB, Groshong JC, Milo GE. (1977). Defective dopaminergic regulation of prolactin secretion in a rat pituitary tumor cell line. Nature. 266:640-1

43. Mansour A, Meador-Woodruff JH, Bunzow JR, Civelli O, Akil H, Weiner DM, Brann MR. (1989). Distribution of D2 dopamine receptor mRNA in rat brain. Proc Natl Acad Sci USA. Oct;86(19):7625-38.

44. McDonald WM, Sibley DR, Kilpatrick BF, Caron MG. (1984). Dopaminergic inhibition of adenylate cyclase correlates with high affinity agonist binding to anterior pituitary D2R dopamine receptors. Mol Cell Endocrinol. Jul;36(3):201-9.

45. McGregor AM, Scanlon MF, Hall R, Hall K. (1979). Effects of bromocriptine on pituitary tumour size. Br Med J. Sep 22;2(6192):700-3.

46. McKay MM, Morrison DK. (2007). Integrating signals from RTKs to ERK/MAPK. Oncogene. May 14;26(22):3113-21.

47. Melmed S, Shimon I. (1998). Management of pituitary tumors. Ann Intern Med. Sep $15 ; 129(6): 472-83$.

48. Metzler B, Hu Y, Sturm G, Wick G, Xu Q. (1998). Induction of mitogen-activated protein kinase phosphatase-1 by arachidonic acid in vascular smooth muscle cells. $\mathrm{J}$ Biol Chem. Dec 11;273(50):33320-6.

49. Missale C, Russle N, Robinson S, Jaber M, Caron M. (1998). Dopamine receptors: from structure to function. Physiological Reviews. 78(1):189-220.

50. Morris AJ, Frohman MA, Engebrecht J. (1997). Measurement of phospholipase D activity. Analytical Biochemistry. Oct 1;252(1):1-9. 
51. Nolte J. (2002). The human brain. An introduction to its functional anatomy. Fifth edition. St. Louis, MO: Moseby, Inc. 353.

52. Ondrey F, Harris JE, Anderson KM. (1989). Inhibition of U937 eicosanoid and DNA synthesis by 5,8,11,14-eicosatetraynoic acid, an inhibitor of arachidonic acid metabolism and its partial reversal by leukotriene C4. Cancer Res. Mar 1;49(5):113842.

53. Owens DM, Keyse SM. (2007). Differential regulation of MAP kinase signalling by dual-specificity protein phosphatases. Oncogene. May 14;26(22):3203-13.

54. Pawlikowski M, Kunert-Radek J, Stepień H. (1978). Direct antiproliferative effect of dopamine agonists on the anterior pituitary gland in organ culture. J Endocrinol. Nov;79(2):245-6.

55. Pettingil OS, Szabo M, Berelowitz M, Sorenson GD, Frohman LA. (1980). Ectopic production of somatostatin-like immuno- and bioactivity by cultured human pulmonary small cell carcinoma. J Clin Endocrinol Metab. Nov;51(5):978-87.

56. Piomelli D, Pilon C, Giros B, Sokoloff P, Martes MP, Schwartz JC. (1991). Dopamine activation of the AA cascade as a basis for D1/D2R receptor synergism. Nature. Sep 12;353(6340):164-7.

57. Piomelli D, Vial D. (1995). Dopamine D2 receptors potentiate arachidonate release via activation of cytosolic, arachidonate-specific phospholipase A2. J Neurochem. Jun;64(6):2765-72.

58. Pouyssegur J, Meloche S. (2007). The ERK1/2 mitogen-activated protein kinase pathway as a master regulator of the G1- to S-phase transition. Oncogene. May $14 ; 26(22): 3227-39$.

59. Prakash N, Wurst W. (2006). Development of dopaminergic neurons in the mammalian brain. Cell Mol Life Sci. Jan;63(2):187-206.

60. Puglisi M, Dolly S, Faria A, Myerson JS, Popat S, O’Brien MER. (2010). Treatment options for small cell lung cancer - do we have more choice? Br J Cancer. Feb 16;102(4):629-38.

61. Roche diagnostics. (1996-2010). Universal probe library. https://www.roche-applied-science.com/sis/rtpcr/upl/ezhome.html. Accessed February 29, 2008.

62. Ross S, Peselow E. (2009). The neurobiology of addictive disorders. Clin Neuropharmacol. Sep-Oct;32(5):269-76.

63. Sasaki K, Sato M. (1987). A single GTP-binding protein regulates K+-channels coupled with dopamine, histamine and acetylcholine receptors. Nature. Jan 1521;325(6101):259-62.

64. Schulz W. (2007). Behavioral dopamine signals. Trends Neurosci. May 1;30(5):20310 .

65. Senogles SE. (1994). The D2R dopamine receptor mediates inhibition of growth in Gh4ZR7 cells: involvement of protein linase C. Endocrinology. Feb;134(2):783-9.

66. Senogles SE. (2000). The D2s dopamine receptor stimulates phospholipase D activity: a novel signaling pathway for dopamine. Mol Pharmacol. Aug;58(2):455-62.

67. Senogles SE. (2003). D2s dopamine receptor mediates phospholipase D and antiproliferation. Mol Cell Endocrinol. Nov 14;209(1-2):61-9.

68. Senogles SE. (2007). D2 dopamine receptor-mediated antiproliferation in a small cell lung cancer cell line, NCI-H69. Anticancer Drugs. Aug;18(7):801-7. 
69. Sigal E. (1991). The molecular biology of mammalian arachidonic acid metabolism. Am J Physiol. Feb;260(2 Pt 1):L13-28.

70. Sillitoe RV, Vogel MW. (2008). Desire, disease, and the origins of the dopaminergic system. Schizophr Bull. Mar;34(2):212-9.

71. Smidt MP, Smits SM, Burbach JP. (2003). Molecular mechanisms underlying midbrain dopamine neuron development and function. Eur J Pharmacol. Nov 7;480(1-3):75-88.

72. Stepień H, Wolaniuk A, Pawlikowski M. (1978). Effects of pimozide and bromocriptine on anterior pituitary cell proliferation. J Neural Transm. 42(3):239-44.

73. Stoof JC, Kebabian JW. (1984). Two dopamine receptors: biochemistry, physiology and pharmacology. Life Sci. Dec 3;35(23):2281-96.

74. Summers ST, Canonico PL, MacLeod RM, Rogol AD, Cronin MJ. (1985). Phorbol esters affect pituitary growth hormone $(\mathrm{GH})$ and prolactin release: the interaction with GH releasing factor, somatostatin and bromocriptine. Eur J Pharmacol. May 20;111(3):371-6.

75. Tashjian AH, Yasamura Y, Levine L, Sato GH, Parker ML. (1968). Establishment of clonal strains of rat pituitary tumor cells that secrete growth hormone. Endocrinology. Feb;82(2):342-52.

76. Taylor AS, Morrison AR, Russell JH. (1985). Incorporation of 5,8,11,14eicosatetraynoic acid (ETYA) into cell lipids: competition with arachidonic acid for esterification. Prostiglandins. Mar;29(3):449-58.

77. Vallar L, Muca C, Magni M, Albert P, Bunzow J, Meldolesi J, Civelli O. (1990). Differential coupling of dopaminergic D2 receptors expressed in different cell types. Stimulation of phosphatidylinositol 4,5-bisphosphate hydrolysis in LtK- fibroblasts, hyperpolarization, and cytosolic-free $\mathrm{Ca} 2+$ concentration decrease in $\mathrm{GH} 4 \mathrm{C} 1$ cells. $\mathrm{J}$ Biol Chem. Jun 25;265(18):10320-6.

78. Volmat V, Pouyssegur J. (2001). Spatiotemporal regulation of the p42/p44 MAPK pathway. J Biol Cell. Sep;93(1-2):71-9.

79. Wang X, Liu Y. (2007). Regulation of innate immune response by MAP kinase phosphatase-1. Cell Signal. Jul;19(7):1372-82.

80. Wass JA, Moult PJ, Thorner MO, Dacie JE, Charlesworth M, Jones AE, Besser GM. (1979). Reduction of pituitary-tumour size in patients with prolactinomas and acromegaly treated with bromocriptine with or without radiotherapy. Lancet. Jul 14;2(8133):66-9.

81. Watson SJ, Mansour A, Meador-Woodruff JH, Bunzow JR, Civelli O, Akil H. (1990). Localization of dopamine D2 receptor mRNA and D1 and D2 receptor binding in the rat brain and pituitary: an in situ hybridization-receptor autoradiographic analysis. J Neurosci. Aug;10(8):2587-600.

82. Weernink PA, Han L, Jakobs KH, Schmidt M, Oude A. (2007). Dynamic phospholipid signaling by $\mathrm{G}$ protein-coupled receptors. Biochim Biophys Acta. Apr;1768(4):888-900.

83. Wise RA. (2004). Dopamine, learning and motivation. Nat Rev Neurosci. Jun;5(6):483-94.

84. Wojcikowski J, Daniel WA. (2009). The brain dopaminergic system as an important center regulating liver cytochrome P450 in the rat. Expert Opin Drug Metab Toxicol. Jun;5(6):631-45. 
85. Zangemeister-Wittke U, Stahel RA. (1999). Novel approaches to the treatment of small-cell lung cancer. Cell Mol Life Sci. Sep;55(12):1585-98.

86. Zhou MM, Farooq A. (2004). Structure and regulation of MAPK phosphatases. Cell Signal. Jul;16(7):769-79. 


\section{VITA}

Scott Lemar Lattimer was born as the son of Beth and Floyd Lattimer in 1972 in Rock Springs, WY. He graduated from Riverton High School in 1990. In January of 1991 he entered the U.S. Army and was honorably discharged in December of 1993. He received a Bachelor of Science degree in Molecular Biology, with a minor in Chemistry from the University of Wyoming in May of 2005. In the fall of 2005 he entered graduate school at the University of Tennessee Health Science Center and expects to receive a Master of Science degree in December of 2010. 